\title{
Deniz Ortamında EI Yapımı Patlayıcı Düzenek (EYPD)'ler Genelinde Terörist Tehditler ve Deniz Güvenliğine Etkileri
}

Terrorist Threat with Improvised Explosive Device (IED) in the Marine Environment and its Effects on Maritime Security

\author{
Murat Kağan KOZANHAN * İbrahim BAYEZİT** \\ $\ddot{O} z$
}

Dünya denizlerinde harp gemileri ile ticari faaliyetlerde kullanilan sivil bahriye gemilerinin, denizel El Yapımı Patlayıcı Düzenek (EYPD) tehdidi ile karşılaşma olasıllı̆̆ bulunmaktadır. Deniz güvenliğinin sağlanması açısından bu tehdidin, neler olduğu ve gelecekte karşılaşılabilecek tehditlerin neler olacağı sorularına yanıt bulunmasının, denizde durumsal farkındalı̆̆ artıracă̆ değerlendirilmektedir. Terör örgütlerinin kullandiğı yöntemler incelendiğinde, deniz ortamının sahip olduğu özellikler sebebiyle, denizel EYPD saldırlarl her gün karşılaşılabilecek tehditler olmamakla birlikte, bu tehdidin göz ardl edilmesi durumunda oluşacak zararlar ve can kayıpları büyük olabilecektir. Yapllan incelemede, terör örgütlerinin denizi kullanarak eylemler yaptıkları ve kendilerini bu alanda gelişstirmeye çalıştıkları

\footnotetext{
* MSÜ Deniz Harp Enstitüsü Dr. Öğretim Üyesi, ORCID: 0000-0003-1747-4723, e-posta: mkkozanhan@msu.edu.tr.

MSÜ Deniz Harp Enstitüsü Komuta ve Kurmay Öğrenci Subay, e-posta: bayezit.ibrahim@gmail.com.
} 
342

Güvenlik Stratejileri

Cilt: 16

Sayı: 34

görülmüş̧ӥr. Bu nedenle, özellikle ticari deniz trafiği üzerinde olumsuz yönde etkilerinin olabileceği sebebiyle, terör örgütlerince yaptlan faaliyetler yakindan takip edilmeli ve gerekli önlemler alınmalıdır. Bu çalışmada; "Deniz Güvenliği" hakkinda genel bilgiler verilmiş, "Denizel EYPD" kavramı detaylı olarak açıklanmış ve deniz ortamında karşılaşılan yeni denizel EYPD'lerin, neler olduğu ve gelişen teknolojinin ışığında gelecekte ne tür denizel EYPD'ler ile karşılaşıllabileceği incelenmiştir.

Anahtar Kelimeler: Deniz Güvenliği, Denizel El Yapımı Patlayıcı Düzenek, Deniz Terörizmi, Karşı Denizel EYPD tedbirleri, Denizde Durumsal Farkindalık.

\section{Abstract}

War Ships and as the backbone of the world's seaborne trade, merchant ships may be subject to similar threats of Maritime IEDs. From a maritime security perspective, the best way to increase situational awareness at seas and ports is to assess the current threats and to foresee future ones. When the methods used by terrorist organizations are examined, it is seen that the Maritime IED attacks are not the daily threats due to the characteristics of the marine environment, but the losses and loss of life could be big if this threat is ignored. As a result of the successful attacks carried out by terrorist organizations, it was understood that they have been working on improving themselves in maritime attacks. Thus, the activities carried out by terrorist organizations should be closely monitored and necessary precautions must be taken, especially as they may have negative effects on commercial maritime traffic.In this study, general information about the "Maritime Security" is given and the concept of Maritime IED is explained in detail. The new Maritime IED's which are encountered in the maritime environment was examined. In the light of these maritime IED's and the developing maritime technologies, was tried to find answers to what kind of Maritime IED's could be encountered in the future.

Keywords: Maritime Security, Maritime Improvised Explosive Device, Maritime Terrorism, Counter Maritime IED, Maritime Situational Awareness. 
Deniz Ortamında El Yapımı Patlayıcı Düzenek (EYPD)'ler Genelinde

Terörist Tehditler ve Deniz Güvenliğine Etkileri

\section{Giriş}

Yemen'in, Umman Denizi kıyısındaki Aden Limanında, demir yerinde akaryakıt ikmali için bekleyen USS Cole ${ }^{1}$ destroyerine, 12 Ekim 2000 tarihinde gerçekleştirilen saldırı dünya üzerinde ilk kez bir savaş gemisine yapılan terörist eylemdir. Saldırıda, 17 denizci hayatını kaybetmiş ve 42 denizci ise yaralanmıştır. El-Kaide'nin üslendiği eylem, iki ayrı intihar bombacısının kullandığı iki süratli fiberglas bot yaklaşık $200 \mathrm{~kg}$ patlayıcı ile USS Cole destroyerinin güvertesinde yaklaşık 12 metre çapında bir yara açılmasına sebep olmuştur. ${ }^{2}$ Dünya üzerindeki küresel ticari faaliyetlerin, hacim olarak \%80'ininden fazlası ve değer olarak \%80'ine yakın kısmı, denizler yoluyla yapılmaktadır. ${ }^{3}$ $\mathrm{Bu}$ nedenle, deniz ortamında terörist faaliyetler sadece savaş gemilerine yapılmamakta, küresel ticaretin can damarını oluşturan ticari kargo gemileri ile enerji ihtiyacını karşılayan petrol tankerleri de hedef alınmaktadır. Nitekim Haziran 2019 ayı içerisinde Basra Körfezinde iki petrol tankerine gerçekleştirilen saldırılarda nasıl yapıldıkları tam olarak tespit edilemese bile birer terörist saldırı olarak tanımlanmıştır.

Bu kapsamda, küresel ticaretin ana güzergâhı diyebileceğimiz, deniz ulaştırma yollarının güvenliği, bu ticarete olan bağımlılığı yüksek olan ülkeler için hayati önemdedir. Ülkeler, deniz ulaştırma yollarındaki ticaret gemilerinin izledikleri rotalarda, karşılaşabilecekleri güvenlik zafiyetlerini önlemek için, çeşitli yöntemler izlemektedirler. Deniz güvenliği çerçevesinde, yüzer unsurların ve deniz ortamının

\footnotetext{
${ }^{1}$ USS Cole (DDG-67), ABD Donanması'nda hizmet veren, Arleigh Burke sınıfi, güdümlü mermi destroyeridir. $154 \mathrm{~m}$ uzunluğundaki destroyerde 220 personel görev yapmaktadır. USS Cole adını, İkinci Dünya Savaşı sırasında, 19 Şubat 1945 günü Iwo Jima'da hayatını kaybeden Darrell S. Cole'dan almaktadır. https://navylive.dodlive.mil/2015/10/12 /determined-warriors-of-todays-uss-cole-draw-inspiration-from-service-and-sacrifice -ofoctober-12-2000/, [Erişim Tarihi: 25.03.2019].

${ }^{2}$ ABD Deniz Kuvvetleri Komutanlığının, saldırı ile ilgili düzenlediği soruşturmaya ait resmi evrak, https://www.history.navy.mil/content/dam/nhhc/browse-by-topic/ships/ uss-cole/pdf/INVESTRPT.pdf, s.8. [Erişim Tarihi: 17.12.2018].

3“"Review of Maritime Transport 2017”, s. 10, https://unctad.org/en/Publications Library/rmt2017en.pdf, [Erişim Tarihi: 17.12. 2018].
}

343

Güvenlik Stratejileri

Cilt: 16

Say1: 34 
344

Güvenlik Stratejileri

Cilt: 16

Sayı: 34

karşılaşacağı riskler ve tehlikeler belirlenmeye çalışılmaktadır.

Teknolojik ilerlemeye bağlı olarak, terörist eylemlerde kullanımları giderek artan EYPD'lerin, deniz ortamında yapılacak terörist saldırılarda uygulama yöntemleri her geçen gün değişmektedir. Yaşanan saldırılardan görüldüğü üzere, terörist örgütler tarafından deniz araçlarına yapılan EYPD saldırılarının verdiği zararlar çok büyüktür. EYPD'lerin deniz ortamında kullanılabilmesi, belirli bir teknik bilgi ve yetenek gerektirmesi sebebiyle, her gün karşılaşılabilecek bir tehdit oluşturmamasına rağmen, terör örgütlerinin bu saldırı yöntemlerini geliştirmeye yönelik bir çaba içinde oldukları görülmektedir.

Türkçe yazında, konu ile ilgili olarak sadece vaka bazlı, sınırlı araştırmalar bulunmaktadır. Ancak, bu çalışmalarda patlayıcı maddeler konusunda uzman olmayan kişilerin yaptığı incelemelerin, kısıtlılıkları mevcuttur. Ayrica, meydana gelen olayların münferiden incelenmesi sebebiyle, geleceğe ilişkin çıkarımlar da olay bazlı olarak yapılabilmektedir. Yapılan çalışmanın, küresel güvenlik ortamında, EYPD tehdidine yönelik olarak deniz güvenliğinde alınacak tedbirler ile geleceğe yönelik tehdit değerlendirmelerine 1şık tutması açısından önemli olduğu değerlendirilmektedir.

Konu ile ilgili kavramsal çerçevenin anlaşılmasına yardımcı olacağ düşünülerek, önce "Deniz Güvenliği”" kavramı hususunda genel bilgiler verilecektir. Deniz güvenliğinin çok geniş bir yelpazede birçok farklı hususu içerisinde barındırmasından dolayı, çalışmada bu kavram konu ile bağlantısı çerçevesinde ele alınacaktır. Bu kısımdan sonra, konunun özünü oluşturan denizel EYPD tehdidine odaklanılacak ve müteakiben mevcut gelişmeler değerlendirilerek geleceğe yönelik tahminlerde bulunulacak ve bu kapsamda alınabilecek tedbirler üzerinde durulacaktır.

\section{Deniz Güvenliği ve Denizel EYPD'LER}

İtalyan bayraklı yolcu gemisi Achille Lauro'nun, 1985 y1lında Filistin Kurtuluş Cephesine mensup dört silahlı terörist tarafindan, İskenderiye açıklarında kaçırılması, ardından İsrail devleti ile 50 kadar Filistinlinin serbest bırakılmasına ilişkin yapılan pazarlıkların netice vermemesi üzerine, engelli bir Yahudi asıllı $A B D$ vatandaşının 
Deniz Ortamında El Yapımı Patlayıcı Düzenek (EYPD)'ler Genelinde

Terörist Tehditler ve Deniz Güvenliğine Etkileri

vurularak denize atılması ve sonrasında yaşanan gelişmeler, tarihte denizde yapılan ilk terörist faaliyeti olarak kayıtlara geçmiştir. ${ }^{4}$ Teröristlerin gemiyi kaçırdıktan sonra içinde bulunan yaklaşık $400 \mathrm{kadar}^{5}$ yolcu ve personelin maruz kaldığ bu tehlike, uluslararası camianın dikkatini bir anda farklı bir yöne çekmiştir. Bu eyleme kadar daha çok "Deniz Emniyeti" (Maritime Safety) olgusu ön planda iken, bu eylem sonrası "Deniz Güvenliği" (Maritime Security) kavramı gündeme gelmiştir. ABD'de 11 Eylül 2001 tarihinde yaşanan terör olayları sonrası, benzer bir saldırının deniz yolu ile yapılabileceği savı ile birlikte küresel güvenlik paradigması yön değiştirerek yoğunluklu olarak "Deniz Güvenliğii" (Maritime Security) olgusunu daha da öne plana çıkarmıştır.

\subsection{Deniz Güvenliği (Maritime Security)}

Uluslararası ilişkiler disiplininde "Deniz Güvenliği (Maritime Security)", hâlen "tartışmalı kavram" statüsünde bulunmakla birlikte 6 , birçok uluslararası örgüt ve kurum bu kavramı tanımlama yoluna gitmiştir. Bugün, denizciliğin tüm yönlerini kapsayan ve denizcilik sektörünün uluslararası alanda düzenlenmesi amacıyla 1948 yılında kurulan, Uluslararası Denizcilik Örgütü (International Maritime Organization-IMO), "Deniz Güvenliği (Maritime Security)", konusunda kapsamlı yaklaşımlarda bulunan, en önemli uluslararası kurumdur. IMO bünyesinde bulunan beş komiteden biri Deniz Emniyeti Komitesi ${ }^{7}$ altında faaliyet gösteren, Deniz Güvenliği Çalışma Grubudur. Bahse

\footnotetext{
${ }^{4}$ Malvina Halberstam, "Terrorism on the High Seas: The Achille Lauro, Piracy and the IMO Convention on Maritime Safety", The American Journal of International Law, Vol.82, No.:2, April 1988, 269-310, p. 269, https://www.org/stable/2203189?seq =1\#_info_tab_contents [Erişim Tarihi: 19.12.2018].

${ }^{5}$ Jeffrey D. Simon, "The Implications Of The Achille Lauro Hijacking For The Maritime Community", https://apps.dtic.mil/ dtic/tr /fulltext/u2/a178441.pdf [Erişim Tarihi: 21.12.2018].

${ }^{6}$ Christian Bueger, "What is Maritime Security?", Marine Policy, 53, 2015, 159-164, s. 159, https://www.resarchgate.net/publication/270107474_What_is_maritime_security, [Erişim Tarihi: 13.12.2018].

${ }^{7}$ Uluslararas1 Denizcilik Örgütü internet sitesi, http://www.imo.org/en/ About/Pages/Structure.aspx, [Erişim Tarihi: 17.12.2018]
}

345

Güvenlik Stratejileri

Cilt: 16

Say1: 34 
346

Güvenlik Stratejileri

Cilt: 16

Say1: 34

konu çalışma grubu tarafından, "Deniz Güvenliği (Maritime Security)", konusunda alınması gereken önlemler ve uyulmas1 gereken kurallar belirlenmektedir. $\mathrm{Bu}$ kurallardan en önemlisi, 11 Eylül saldırıları sonrası şekillenen yeni güvenlik ortamında, IMO tarafindan deniz güvenliğine yönelik olarak geliştirilen, "Uluslararası Gemi ve Liman Güvenliği (International Ship and Port Facilities Security-ISPS)"” kurallarıdır. Bu kurallar, IMO tarafindan 1 Kasım 1974 tarihinde kabul edilen "Denizde Can Emniyeti Uluslararası Sözleșmesi'nin (International Convention for the Safety of Life at Sea-SOLAS)" 11'inci bölümüne eklenmiştir. SOLAS bölüm 11, birinci kısımda "Deniz Emniyeti (Maritime Safety)" konusundaki önlemler bulunurken, ikinci kısımda bulunan ISPS kuralları; zorunlu hükümleri içeren A kısmı ve zorunlu hükümlerin etkili bir şekilde yerine getirilmesi için tavsiyeleri içeren B kısmı olarak teşkil edilmiştir. ${ }^{9}$

"Deniz Güvenliği (Maritime Security)", kavramına, Kuzey Atlantik Antlaşması Örgütü (NATO) içerisindeki yaklaşımlar açısından baktığımızda; 2010 yılında onaylanan NATO Stratejik Konsepti ışığında geliştirilen, Müttefik Deniz Stratejisi belgesine, deniz güvenliği kavramının ilave edildiği görülmektedir. NATO'nun tanımına göre "Deniz Güvenliği (Maritime Security)", "Ulusal ve Uluslararası hukuka tâbî olan deniz ortamında seyir hakkının korunduğu, vatandaşlar, gemiler, altyapılar ve kaynakların emniyette olduğu sürekli durumdur." şeklinde tanımlanmaktadır. ${ }^{10}$ NATO'nun 2011 yılında onaylanan Deniz Güvenlik Harekâtı (Maritime Security Operation-MSO) Konsepti içerisinde detaylandırılan konulara bakıldığında, üye ülkelerin;

- Denizde Durumsal Farkındalığın Desteklenmesi,

- Seyir Serbestisinin Korunmas1,

8 Maritime (ISPS Code) Regulations 2014, http://extwprlegs1.fao.org/docs/pdf/ fij152587.pdf, [Erişim Tarihi: 17.12.2018].

IMO Deniz Güvenliği Manueli V2, http://www.security.gr/wp-content/ uploads/2015/03/imo-Maritime-Security-Manual.pdf, [Erişim Tarihi: 17.12.2018].

${ }^{10}$ NATO Resmi İnternet Sitesi, “Alliance Maritime Strategy", https://www.nato.int/ cps/ua/natohq/official_texts_75615.htm, [Erişim Tarihi: 17.12.2018]. 
Deniz Ortamında El Yapımı Patlayıcı Düzenek (EYPD)'ler Genelinde Terörist Tehditler ve Deniz Güvenliğine Etkileri

- Denizde Denetim Harekât1,

- Kitle İmha Silahlarının (KİS) Yayılımının Önlenmesi,

- Denizde Terörizmle Mücadeleye Destek,

- Kritik Altyapının Korunması,

- Deniz Güvenliğine Yönelik Yetenek Oluşturulmasına Katk1

konularında görevler icra etmelerinin hedeflendiği belirtilmektedir. Deniz Güvenliğine yönelik icra edilen, NATO faaliyetlerine bakıldığında, 11 Eylül saldırılarından hemen sonra Akdeniz'de terörist faaliyetler ile mücadele maksatlı oluşturulan Etkin Çaba Harekâtı (Operation Active Endeavour), 2016 yılı sonunda Deniz Muhafizı Harekatı'na (Operation Sea Guardian) dönüştürülmüştür. Bu dönüşüm neticesinde, NATO Deniz Güvenlik Harekâtı Konseptinde yer alan hedeflerden; "Denizde Durumsal Farkındalığın Desteklenmesi", "Denizde Terörizmle Mücadeleye Destek" ve "Deniz Güvenliği Yetenek Oluşturulmasına Katkı" görevleri icra edilmektedir. ${ }^{11}$ Bir NATO üyesi olarak Türkiye'de Deniz Kuvvetleri marifeti ile bahse konu harekata yüzer, dalar ve uçar unsurlar ile destek vermektedir.

Avrupa Birliği’nin (AB) "Deniz Güvenliği” konusuna yaklaşımı ise, 2014 y1lında oluşturduğu "Deniz Güvenliği Stratejisi” ile tanımlama yoluna gittiği kavram, NATO'nun tanımlamasiyla hemen hemen benzer ifadeleri içermekte ve ilave olarak "çevrenin korunmasını" da kapsamına dahil etmektedir. ${ }^{12}$ AB'nin "Deniz Güvenliğì" kapsamında icra ettiği faaliyetler aşağıda sunulduğu gibidir;

- 2007 yılında, AB Sınır ve Sahil Güvenlik Ajansı (FRONTEX) tarafindan icra edilen ve $\mathrm{AB}$ sınırlarında insan kaçakçılığı başta olmak üzere, her türlü kaçakçılık ve terörist faaliyetlerle mücadele harekâtları,

- 2008 yılında, Somali merkezli deniz haydutluğu ve silahlı soygun olaylarına karşı mücadele etmek amacıyla oluşturulan

11 NATO Resmi İnternet Sitesi, "NATO's Maritime Activities", https://www.nato.int/cps/en/natohq/topics_70759.htm [Erişim Tarihi: 20.12.2018].

12 "European Union Maritime Security Strategy", ttp://register.consilium.europa.eu/ $\mathrm{doc} / \mathrm{srv} ? \mathrm{l}=\mathrm{EN} \& \mathrm{f}=\mathrm{ST} \% 2011205 \% 202014 \% 20$ INIT, p. 7, [Erişim Tarihi: 19.12.2018]. 
348

Güvenlik Stratejileri

Cilt: 16

Sayı: 34

AB Deniz Gücü ATALANTA Harekâtı (EU Naval Force (EUNAVFOR) Operation ATALANTA),

- 2012 yılında, Somali’nin deniz güvenliği konusundaki kapasitesinin arttırılmasına yönelik oluşturulan AB Somali'de Deniz Gücü Kapasite Oluşturma Görevi (EU Maritime Capacity Building Mission in Somalia-EUCAP-Somalia),

- 2015 y1lında, AB'nin Akdeniz'de deniz yoluyla göçmen kaçakçılığı ile mücadele etmek maksadiyla oluşturduğu $\mathrm{AB}$ Deniz Gücü-"Akdeniz" SOPHIA Harekâtı (EU Naval Force-"Mediterranian" (EUNAVFOR MED) Operation SOPHIA. ${ }^{13}$

Deniz güvenliği kavramının ulusları aşan bu niteliği sebebiyle, uluslararası kamuoyunun dikkatini çekebilmek adına, Birleşmiş Milletler (BM) Genel Sekreteri Ban Ki-Moon tarafindan 2008 yılında sunulan bir raporda, deniz güvenliğine yönelik tehditler; deniz haydutluğu ve silahlı soygun, terörist faaliyetler, KİS yayılması ve silah kaçakçıllı̆ yasa dişı uyuşturucu trafiği, deniz yolu ile insan kaçakçılığı, yasa dış1 balıkçıllk ve deniz kirliliğ $i^{14}$ olarak belirtilmiştir. Raporda ayrıca, bahse konu tehditlere yönelik, uluslararası iş birliğine ve yeni bir güvenlik anlayışına ihtiyaç olduğu vurgusu yapılmıştır. Deniz güvenliğine yönelik bilgilerin ve icra edilen faaliyetlerin genişliği başka bir çalışmanın konusu olabilir ancak, çalışmada odaklanılmak istenen esas nokta, deniz güvenliği kapsamında, deniz ortamında teröristler tarafindan kullanılan EYPD'lerdir.

\subsection{El Yapımı Patlayıcı Düzenekler ve Denizel EYPD Kavramı}

İngilizce kaynaklarda, Improvised Explosive Device (IED) olarak yer alan EYPD, çok uzun zamandır kullanılan bir çeşit silah olarak tanımlanabilir. BM, EYPD'leri "Yerleştirilen veya geliştirilmiş

13 AB Resmi İnternet Sitesi, "Maritime Security Strategy", https://ec.europa.eu/ maritimeaffairs/policy/maritime-security_en, [Erişim Tarihi: 17.12.2018].

14 BM Resmi İnternet Sitesi, "Oceans and The Law Of The Sea", http://www.un.org/en/development/desa/population/migration/generalassembly/docs/ globalcompact/A_RES_63_111.pdf, p. 3, [Erişim Tarihi: 20.12.2018]. 
Deniz Ortamında El Yapımı Patlayıcı Düzenek (EYPD)'ler Genelinde

Terörist Tehditler ve Deniz Güvenliğine Etkileri

bir şekilde üretilen, yıkıcı, öldürücü, zehirli, yangın çıkarıcı, piroteknik malzemeler ${ }^{15}$ veya kimyasallar içerebilen, yok etmek, bozmak, rahatsız etmek veya taciz etmek için tasarlanmış, patlayıcı maddeler ihtiva eden düzenekler"16 olarak tanımlamaktadır. Türkçe yazında "El Yapımı Patlayıcı" (EYP) tanımlamasının yaygın olarak kullanılmasına karşın bu tanımlamanın tam anlamıyla EYPD kavramını karşıladığını söylemek güçtür. Çünkü, patlayıcı maddelerin tek başlarına, herhangi bir düzeneğe bağlı olmaksızın infilak ettirilebilmesi çok zordur. "Ev Yapımı Patlayıcı" (Homemade Explosive-HME) kavramının da literatüre yaygın şekilde girmesiyle birlikte, kavramların karışmasına mâni olmak adına EYPD'nin kavramsallaştırılmasının daha uygun olacağı değerlendirilmektedir. EYPD kavramın daha iyi anlaşılabilmesi için bir EYPD'nin ana elamanlarına kısaca değinmek yerinde olacaktır;

- Anahtar veya Başlatma Mekanizması (Switch); basınç, zaman gecikmesi, hareket, uzaktan/radyo kontrol veya diğer yöntemlerle düzeneğin tetiklenmesi.

- Enerji Kaynağı (Power Source); genellikle düzeneğin başlatıcısı veya fünyesinin infilak ettirilmesi için gerek duyulan elektrik enerjisini sağlayan batarya veya akü.

- Başlatıcı veya Fünye (Initiator); infilakın başlatılabilmesi için gerek duyulan şok ve 1sıyı üreterek ana patlayıcının infilak etmesini sağlayan; ticari, askeri veya ev yapımı (home-made) fünyeler.

- Dış Kap (Compartment); ana patlayıcı dolgusunu ve düzeneği taşımak maksadıyla kullanılan kaplardır. Bir çantadan, çocuk oyuncağına, düdüklü tencereden çaydanlığa kadar değişebilen geniş bir yelpazedeki dış kaplar, hedefe göre şekilli şarj tesiri gösterebilecek

\footnotetext{
${ }^{15}$ Piroteknik 1S1, 1şık, gaz, duman ve/veya ses üretmek için bağımsız olarak kendinden ekzotermik kimyasal reaksiyonları sürdürme yeteneğine sahip maddeler.

${ }^{16}$ BM Uluslararası Mühimmat Teknik Rehberi "United Nations International Ammunition Technical Guidelines (IATG) 01.40, 2015(E) 2nd Edition (2015-02-01), https://s3.amazonaws.com/unoda-web/wp-content/uploads/2016/11/IATG-01.40Glossary-and-Definitions-V.2.pdf, p. 16, [Erişim Tarihi: 18.12.2018].
}

\section{9}

Güvenlik Stratejileri

Cilt: 16

Say1: 34 
350

Güvenlik Stratejileri

Cilt: 16

Sayı: 34 özelliklerde olabileceği gibi parça tesirini arttırabilmek için demir bilye veya çiviler de ihtiva edebilir.

- Patlayıcı Madde (Explosive); ana patlayıcı dolgusu, ev yapımı patlayıcı (amonyum nitrat (gübre) bazlı patlayıcılar) veya askeri patlayıcı (cephaneliklerden çalınan askeri mühimmatlar, savaş artığ 1 patlayıcılar ve atılıp patlamamış mühimmatlar) olabileceği gibi ticari olarak kullanılan dinamit veya kara barut benzeri patlayıcı maddelerde kullanılabilir. $^{17}$

EYPD ana elamanlarının, BM Silahsızlanma Araştırmaları Enstitüsü raporundaki tanımında, genel olarak kabul gören 5 elemanın baş harflerinden oluşan, SPICE kodlaması ile hatırlanması kolay hale getirilmeye çalışılmışıır ${ }^{18}$. EYPD'lerin sınıflandırması konusunda birçok farklı yaklaşım bulunmakla beraber genel kabul gören sınıflandırma şu şekildedir:

- Seçilmiş Kişi (Kurban) Başlatmalı EYPD’ler (Victim Operated IED-VOIED's),

- Kablo Komutalı EYPD'ler (Command Wire IED-CWIED's),

- Uzaktan Komutalı EYPD'ler (Remote (Radio) Controlled IEDRCIED's),

- Araç Tipi EYPD'ler (Vehicle-Borne IED-VBIED's),

- İtihar Bombaları (Suicide Bomb's IED-SBIED's),

- Denizel EYPD'ler (Water-Borne/Maritime-MIED's).

Hedef alınan unsur tarafindan yapılan hareketler (basma, çekme, gergiden kurtulma vb.) ile infilak eden Seçilmiş Kişi (Kurban) Başlatmalı EYPD'ler, savaş alanlarında en çok rastlanan bubi tuzağı benzeri basit düzeneklerdir. Kablo Komutalı EYPD'ler, uzaktan kumanda teknolojilerinin gelişmediği dönemlerde teröristlerin tercih ettiği ve çok uzak mesafelere kablolar çekerek kendi kaçış noktalarını oluşturdukları

17 BM Silahsızlanma Araştırmaları Enstitüsü (UNIDIR), “Addressing Improvised Explosive Devices" Report, p.15, http://www.unidir.org/files/publications/pdfs/-en641.pdf, [Erişim Tarihi: 18.12.2018].

${ }^{18}$ Ibid, p. 15. 
düzeneklerdir. Telsiz ve cep telefonu teknolojilerinin yaygınlaştı̆̆ dönemde geliştirilen Uzaktan Komutalı EYPD'ler, radyo frekansının kullanılmasıyla uzak mesafelerden tetiklenebilen düzeneklerdir. Terör örgütlerinin, sinyal karıştırıcı (Jammer) sistemlerinin gelişmesiyle birlikte; uzaktan komuta sistemlerinde ve EYPD'nin uzaktan komuta sistemini sinyal karıştırıcıların etki mesafesinin dışında tutabilmek için farklı yöntemler geliştirmektedirler.

Yazılı tarihte ilk örneklerine Napolyon dönemi Fransa'sında ${ }^{19}$ rastlanılan "Araç Tipi EYPD" ler, bu dönemde tahmin edileceği üzere at arabaları veya faytonlara tuzaklanan patlayıcı düzeneklerdir. Teknolojinin gelişmesine paralel olarak otomobillerin yaygınlaşması ile çatışma alanlarının büyük çoğunluğunda görülmeye başlanan "Araç Tipi EYPD" ler, yüksek miktarda patlayıcı taşımaları ve infilak ettirilmeleri ile birlikte, büyük hava basıncı (blast) ve çok miktarda parça tesiri yaratmaları sebebiyle daha yıkıcı/kırıcı ve ölümcül bir tehdit haline gelmiştir. Karayollarında görülen her tür araç bu maksatla kullanılabileceği gibi araçların hem hareket halinde hem de park halinde iken terörist eylemlerde kullanıldığı gözlemlenmektedir. Dünya'nın her yerinde terörist amaçlar için kullanılan "Araç Tipi EYPD” ler, halen iç karışıklıkların devam ettiği Irak ve Afganistan'da çok çeşitli şekillerde terörist örgütler tarafindan kullanılmaktadır. Bu konuya örnek vermek gerekirse, Suriye ve Irak'ta faaliyet gösteren DAEŞ terör örgütünün tek başına 2016 yılında yaptığı Araç Tipi EYPD saldırısı sayısı $815^{\prime}$ tir. $^{20}$

İntihar Bombacıları kategorisinde ise karşımıza bambaşka bir boyut çıkmaktadır. Terör örgütlerinin, beyin yıkama teknikleri ve ilaçlar kullanarak yönlendirdiği kişilerin, üzerlerinde taşıdıkları patlayıcı düzenekleri infilak ettirmeleri neticesinde gerçekleşen saldırılar, genel itibari ile medyada çok büyük ses getirmektedir. Dini duyguların yoğun

${ }^{19}$ James Revill, Improvised Explosive Devices The Paradigmatic Weapon of New Wars, Palgrave Macmillan, Brighton, UK, 2016, p. 7.

${ }^{20}$ Action on Armed Violance 2017 Raporu, "Improvised Explosive Device (IED) Monitor 2017", Norveç, 2017, p.26, https://reliefweb.int/sites/reliefweb.int/files/ resources/IED-Monitor-Report-for-web-final.pdf, [Erişim Tarihi: 20.12.2018]. 
352

Güvenlik Stratejileri

Cilt: 16

Sayı: 34 şekilde sömürüsü ile güdülenen saldırganların üzerinde bulunan düzenekler, bazı saldırılarda saldırganın son anda vazgeçebileceği düşüncesiyle başka bir kişi tarafından uzaktan infilak ettirilebilecek şekilde dizayn edilmektedirler.

EYPD'ler son dönemde gerek savaş ortamlarında gerekse terör eylemlerinde kayıp verdirilmek üzere en çok başvurulan saldırı yöntemi olmuştur. Ancak, EYPD'lerin bu geniş dünyasında bizim esas odaklanmak istediğimiz nokta Denizel EYPD'lerdir. Bu kapsamda müteakip bölümde mavi sulara kan karıştıran bu düzeneklere ait derinlemesine bilgiler verilecektir.

\subsection{Denizel EYPD'ler}

İngiliz literatüründe Maritime IED olarak geçen kavram, ABD menşeili kaynaklarda Water-Borne IED olarak kullanılmaktadır. Türkçe literatürün çok sınırlı olduğu ve herhangi bir kavramsallaştırmanın yapılmadığı bu düzenekler için "Denizel EYPD" kavramının uygun olduğu değerlendirilmektedir.

"Denizel EYPD”ler çok farklı formlarda karşımıza çıkabilmektedir. Bunlar; yüzen geliştirilmiş mayınlar, sualtı ve su üstü intikal vasıtaları, savaş yüzücüleri veya dalgıçlar tarafından taşınan düzenekler (Limpet Mayın vb.), patlayıcı yüklü insanlı veya insansız botlar olabileceği gibi ziyaret veya zapt ve müsadere edilecek araçlarda bulunabilecek bubi tuzağı benzeri EYPD'ler de olabilir. ${ }^{21}$

Her ne kadar konvansiyonel bir silah olarak dizayn edilmiş olsa da deniz mayınları içerisinde yer alan "limpet mayınlar", "denizel EYPD” olarak kullanılması ilk akla gelen düzeneklerdir. İkinci Dünya Savaşı başlangıcında İngiliz mühendisler tarafından geliştirilen "limpet mayınlar" 22 temel olarak kuvvetli mıknatıslar ile gemi karinasina

21 Jonathan L. Mocker, Maritime Improvised Explosive Devices: A Threat Based Technology Study, Yüksek Lisans Tezi, U.S. Army Command and General Staff College, 2015, s. 1, https://apps.dtic.mil/dtic/tr/fulltext/u2/a624055.pdf, [Erişim Tarihi: 10.02. 2019].

${ }^{22}$ "The Creation of the Highly Effective Limpet Mine", https://www.warhistory online.com/instant-articles/creation-of-the-limpet-mine.html, [Erişim Tarihi: 18.02.2019]. 
yerleştirilen zaman gecikmeli “denizel EYPD” lerdir. Gemi karinalarında zamanla oluşan deniz kabuklu canlılarından olan deniz minarelerine benzerliği sebebiyle İngilizlerce bu mayınlara limpet ismi verilmiştir. İngilizler tarafindan "Limpet Mayınların" İkinci Dünya Savaşı boyunca, etkili bir biçimde hem denizde hem de karada kullanılmaları, bu silahın diğer ülkelerce de üretimine başlanmış ve birçok modeli geliştirilmiştir. Halen yirmiden fazla ülke tarafindan üretilmekte olan "Limpet Mayınlar", savaş yüzücüleri veya sualtı tahrip timleri tarafindan düşman gemi karinasına özellikle şaft, pervane veya dümen yelpazesi bölümlerine yerleştirilerek gemilerin harekâttan sakıt kalmasını sağlamaktadır.

"Limpet Mayın"ların yanı sıra diğer deniz mayınlarının da içerdikleri yüksek miktarda patlayıcı ve deniz ortamına dayanıklı olmaları sebebi ile "Denizel EYPD" olarak kullanılması beklenmektedir. Deniz tabanında bulunan dip mayınlarının her ne kadar bu maksatla kullanımlarına rastlanmasa da demirli mayınların sabit kalmasını sağlayan zincirlerinden koptuğu andan itibaren bir "Denizel EYPD" ye dönüştügünü söylemek yanlış olmayacaktır. Serseri mayın olarak da ifade edilen bu mayınlar, akıntı ve rüzgârın etkisiyle deniz ulaştırma yolları üzerindeki gemi trafiği için büyük tehlike yaratmaktadır. Bahse konu mayınlar İran-Irak savaşında Irak tarafından Basra Körfezinde kullanılmıştır. ${ }^{23}$

Demirli deniz mayınlarının, temelde üzerinde bulunan ateşleme mekanizmasının gemi karinasına çarpmasıyla infilak eden düzenekler olduğu düşünüldüğünde, bu basit düzeneği terör örgütlerinin kendi imkânları ile imal edebilecekleri mayınlarda da kolayca uygulayabileceklerdir. Fabrikasyon deniz mayınlarının özellikleri ile kıyaslandığında deniz ortamına dayanımları ve hassasiyetlerinin düşük olabileceği öngörülen bu tarz "Denizel EYPD" lerin, deniz ulaştırma yolları üzerindeki kritik boğaz ve geçitlerde büyük bir tehdit

\footnotetext{
${ }^{23}$ CIA Resmi İnternet Sitesi, The Iranian Mine Warfare Threat, p. 3, https://www.cia.gov/ library/readingroom/docs/CIA-RDP85T00314R000300100002-7.pdf (Erişim Tarihi: 31.03.2020)
}

\section{3}

Güvenlik Stratejileri

Cilt: 16

Say1: 34 
354

Güvenlik Stratejileri

Cilt: 16

Sayı: 34 oluşturabileceği anlaşılmaktadır.

"Denizel EYPD” lerin hedef platforma ulaştırılması çok farklı yöntemler ile gerçekleştirilebilir. Savaş yüzücüsü veya dalgıç kullanılarak yapılan saldırılarda patlayıcı miktarının yüzücü veya dalgıcın taşıyabileceği miktar ile kısıtlı olacağı düşünülebilir. Ancak, yüzdürme özelliği olan yüksek yoğunluklu polietilen tipteki malzemeler ile patlayıcının sudaki ağırlığı istenilen ölçüde azaltılabilir. Bu imkânlar sayesinde, yüzücü veya dalgıcın sadece üzerinde taşıdığı patlayıcılar ile değil yüzdürebildiği yüksek miktarlardaki patlayıcı ile de büyük zararlar verebilecek saldırılar gerçekleştirebileceği değerlendirilmelidir. Bu kapsamda, ilk örnekleri çok küçük ebatlarda olan "Limpet Mayın" ların bugün bazı modellerinin patlayıcı ağırlıklarının $5 \mathrm{~kg}$ ile $100 \mathrm{~kg}$ arasında olduğu bilinmektedir. ${ }^{24}$

Patlayıcı yüklü sürat tekneleri yakın dönemde belki de en çok kullanılan ve en etkili "Denizel EYPD" lerdir. ${ }^{25}$ Bahse konu teknelerin özellikleri itibari ile olabildiğince süratli intikal etmeleri ve mümkün olduğunca radara yakalanmamaları hedeflenmektedir. $\mathrm{Bu}$ maksatla özel olarak dizayn edilmiş sürat tekneleri kullanılabileceği gibi normal bir fiberglas botun veya teknenin içine patlayıcılar yüklenerek, insanlı veya insansız olarak hedefe yönlendirilmesi mümkündür.

Deniz teknolojilerinde yaşanan gelişmelere paralel olarak insansız sualtı araçlarının ve sualtı intikal vasıtalarının da kullanımı her geçen gün artmaktadır. Temelde bilimsel araştırma, keşif ve gözetleme amaçlı dizayn edilen "İnsansız Sualtı Araçları (Unmanned Underwater Vehicle-UUV)" nın, otonom özellikler kazanması (Autonomous

${ }^{24}$ James Bonomo, Giacomo Bergamo, David R. Frelinger, John Gordon and Brian A. Jackson, Stealing the Sword, What Types of Advanced Military Weapons Could Become Available to Terrorists?, RAND Corporation, 2007, p. 2. https://www.jstor.org/stable/ 10.7249/mg510dhs.10?seq=1\#metadata_info_tab_contents (Erişim Tarihi: 31.03.2020)

${ }^{25}$ Christopher Martin, "The Historical Use of Maritime Improvised Explosive Devices", Hull University Centre for Security Studies IED Project Occasional Paper No. 1, 2010, p. 8, http://www.wbied.com/wp-content/uploads/2015/08/wbied.com_ CSS-Occasional-Paper-1.pdf, [Erişim Tarihi: 10.02.2019]. 
Deniz Ortamında El Yapımı Patlayıcı Düzenek (EYPD)'ler Genelinde

Terörist Tehditler ve Deniz Güvenliğine Etkileri

Underwater Vehicle-AUV) ${ }^{26}$ ile bir "Denizel EYPD" olarak kullanılabileceği öngörülmektedir.

"Denizel EYPD" olarak değerlendirilebilecek bir diğer saldırı yöntemi de mini denizaltı veya cep denizaltısı olarak bilinen su altı vasıtalarıdır. Ticari ve turistik maksatlı su altı intikal vasıtalarının (su altı scooterları vb.) teröristlerin uzak mesafelere intikalini kolaylaştırabileceği ve sürat avantajı sağlayacağı açıktır. Uyuşturucu ve yasadışı göçmen kaçakçılığı gibi faaliyetlerde kullanım örnekleri görülen ${ }^{27}$ bu araçların terör örgütleri tarafından çok farklı amaçlarla kullanılabilecektir. Ticari ve turistik maksatlı su altı intikal vasitalarının (su altı scooterları vb.) teröristlerin uzak mesafelere intikalini kolaylaştırabileceği ve sürat avantajı sağlayacağı açıktır. Genel itibari ile bir veya iki kişi tarafından idare edilen bu vasıtaların boyutsal olarak yüksek miktarda patlayıcı ile hedef platforma saldırması sonucu hedef platforma büyük hasar verdirebilir. Temel olarak, deniz ortamında bulunan; yüzer unsurlar, petrol platformları ve benzeri sabit tesisler ile kablo ve boru hatları gibi krtik altyapılar ile personele tehdit oluşturan patlayıcı ihtiva eden bütün düzenekleri "denizel EYPD" olarak değerlendirmek mümkündür. $\mathrm{Bu}$ kapsamda, çalışmanın müteakip bölümünde, USS Cole saldırısından günümüze kadar geçen zaman zarfında karşılaşılan "denizel EYPD" saldırıları incelenecek ve yeni trendlerin neler olduğu belirlenmeye çalışllacaktır.

\section{Yakın Geçmişte Karşılaşılan "Denizel EYPD” Saldırıları ve Yeni "Denizel EYPD" Trendleri}

USS Cole saldırısından yaklaşık 2 yıl sonra, 6 Ekim 2002 tarihinde, Yemen'in Ash Shihr Limanında demirleme manevrası esnasında,

\footnotetext{
${ }^{26}$ Güray Ali Canlı ve diğ., "Dünyada Ve Ülkemizde İnsansız Sualtı Araçları (İSAAAUV \& ROV) Tasarım ve Uygulamaları", ITÜ Gemi Inşaatı ve Deniz Bilimleri Fakültesi Dergisi, Say1 4, 2015: s. 44.

${ }^{27}$ Yarın Eski, 'Diving for dope': Identity in submarine drug policing at the 'maritime gateway to Europe', European Journal of Criminology, First Published, November 18, 2019, s.2, https://doi.org/10.1177/1477370819887513.
} 
356

Güvenlik Stratejileri

Cilt: 16

Sayı: 34

Fransız tankeri MV Limburg'a gerçekleştirilen saldırıda, El-Kaide örgütü tarafından yine patlayıcı yüklü süratli bot yöntemi kullanılmış ve biri gemi mürettebatı, toplam üç kişi hayatını kaybetmiştir. Tankerin, saldırı esnasında 297 bin varil ham petrol taşıması ve bunun

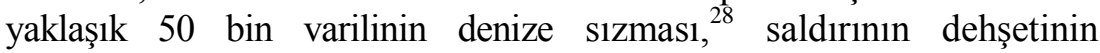
anlaşılması açısından önemlidir. Saldırı yarattığı büyük deniz kirliliğinin yanında artan sigorta maliyetleri nedeniyle petrol fiyatlarında varil başına 0,48 dolarlık bir artışa sebep olmuştur. ${ }^{29}$

USS Cole ve MV Limburg saldırılarının planlayıcısı olmak suçundan 2002 yılında yakalanan ve Küba'daki Guantanamo Hapishanesi'nde tutulan, El-Kaide'nin Arap yarımadası sorumlusu Abd al-Rahim al NASHİRI'nin örgüt içinde "Denizlerin Prensi" kod adıyla ün salmasına sebep olan saldırılar, dikkatleri bir anda "Denizel EYPD”lerin etkinliğine çekmiştir. Nashiri yakalandığından yanında 180 sayfalık denizde saldırılabilecek hedef gemi listesi bulunmuştur. ${ }^{30}$ Yapılan sorgulamalar ve aramalardan sonra Nashiri'nin saldırılarını 4 farklı yöntem üzerine temellendirdiği anlaşılmıştır. ${ }^{31} \mathrm{Bu}$ yöntemler:

- Patlayıc1 yüklü süratli botlar kullanarak askeri veya sivil gemilere saldırmak,

- Orta büyüklükte tekneleri limanlarda ya da gemilerin yanında patlatarak zarar vermek,

- Uçakları kullanarak gemilere saldırmak,

\footnotetext{
${ }^{28}$ Joshua Ho, Catherine Zara Raymond, The Best Of Times, The Worst Of Times: Maritime Security in the Asia-Pacific, World Scientific Publishing, Londra, 2005, p. 164.

${ }^{29}$ OECD Maritime Transport Committee, "Security in Maritime Transport: Risk Factors and Economic Impact", 2003, p. 3, http://www.oecd.org/newsroom/4375896.pdf, [Erişim Tarihi: 13.02.2019].

${ }^{30}$ Ashley Moore, "Needed: Revisions to Maritime Response Standard", Total Integrated Preparedness Solutions (T.I.P.S.), c. 1, s. 7, April 2005, p. 1, https://www.domprep.com/ resilience/needed--revisions-to-maritime-response-standard/ [Erişim Tarihi: 13.02.2019].

${ }^{31}$ Akiva J. Lorenz, “Al Qaeda's Maritime Threat”, Intelligence and Terrorism Information Center at the Israel Intelligence Heritage \& Commemoration Center (IICC), 3 May 2007, p. 13, http://citeseerx.ist.psu.edu/viewdoc/download?doi=10.1.1.473.6168\&rep=rep1\& type $=$ pdf, [Erişim Tarihi: 13.02.2019].
} 
Deniz Ortamında El Yapımı Patlayıcı Düzenek (EYPD)'ler Genelinde

Terörist Tehditler ve Deniz Güvenliğine Etkileri

- Su Alt1 Tahrip timlerine sahip olmaktır.

Nashiri'nin 2002 yılında tutuklanana kadar olan süreçte yaptığ planlamalar incelendiğinde; Cebelitarık ve Hürmüz boğazlarından geçen Amerikan savaş gemilerine ve Bahreyn'de bulunan Amerikan 5'inci Filosu'nun karargahına saldırı yolları aradığı ilave olarak, Birleşik Arap Emirlikleri'nin Rashid Limanı'nda demirli Amerikan savaş gemilerine küçük uçaklar ile intihar saldırısı düzenlemek için pilot arayışında olduğu anlaşılmıştır. ${ }^{32}$ Yemen hükümeti tarafından idam cezas1 verilen Nashiri, halen Guantanamo Hapishanesi'nde ABD makamları tarafından tutulmakta olan en önemli 15 tutuklu arasında ${ }^{33}$ yer almakta ve yargilanmasina devam edilmektedir.

2004 Yılında, Irak Savaşı neticesinde yönetimden ayrılan Saddam Hüseyin'in yerine seçilen yeni Irak Hükümeti'nin ekonomik istikrarını sarsmak maksadıyla Khor Al-Amaya ve Al Basra açık deniz petrol terminallerine gerçekleştirilen patlayıcı yüklü bot saldırılarında ${ }^{34}$ yine benzer teknikler kullanılmış ancak bu saldırıların ekonomik maliyeti çok daha büyük olmuştur. Abu Musab Al-Zarqawi tarafından üstlenilen saldırılar neticesinde Irak ekonomisi 28 milyon dolardan ${ }^{35}$ fazla zarar görmüştür.

24 Nisan 2004 tarihinde yine aynı bölgede görev yapan Amerikan Deniz Kuvvetleri'ne ait karakol gemisi USS Firebolt, rutin karakol faaliyetlerini yürütürken karşılaştığı şüpheli bir balıkçı teknesini denetlemek maksadıyla, 7 kişilik gemiye çıkma ve emniyete

\footnotetext{
${ }^{32}$ Guantanamo Tutuklu Biyografileri, https://archive.defense.gov/pdf/detainee biographies1.pdf, p.7, [Erişim Tarihi: 13.02.2019].

33 "In Guantánamo, an alleged al-Qaeda killer awaits trial”, https://www.economist.com /international/2017/01/14/in-guantanamo-an-alleged-al-qaeda-killer-awaits-trial, [Erişim Tarihi: 13.02.2019].

${ }^{34}$ Martin N. Murphy, Contemporary Piracy and Maritime Terrorism: The Threat to International Security, International Institute of Strategic Studies, Routledge/İngiltere, 2007, p. 107

${ }^{35}$ Ibid, p. 108.
}

\section{7}

Güvenlik Stratejileri

Cilt: 16

Say1: 34 
Güvenlik Stratejileri

Cilt: 16

Sayı: 34

alma (Boarding) timini tekneye gemi vasıtasıyla göndermiştir. ${ }^{36}$ Boarding timinin balıç̧ı teknesine yanaşmasını müteakip, intihar bombacısı patlayıcıları patlatmış ve üç personelin hayatını kaybetmesine ve geri kalanların da ağır yaralanmasına sebep olmuştur. ${ }^{37}$

2004 yılında denizde yaşanan saldırılardan belki de en akılda kalanı, şüphesiz Filipinler'e ait Super Ferry 14 isimli 10.000 tonluk yolcu gemisine ${ }^{38}$ yapılan bombalı saldırıdır. Filipinler'in güneyinde Jolo ve Basilan adalarında faaliyet gösteren radikal silahlı bir örgüt olan Ebu Seyyaf Grubu tarafından üstlenilen saldırıda, gemiye sokulan bir televizyon içerisine gizlenmiş 20 dinamit lokumunun ${ }^{39}$ infilak ettirilmesi sonucu, büyük bir yangın çıkmış ve 116 kişi hayatını kaybetmiştir. $^{40}$

Patlayıcı yüklü tekneler ile yapılan bir diğer saldırı girişimi, ülkemize turistik amaçla gelen İsrail ve ABD vatandaşlarının bulunduğu bir yolcu gemisine Antalya açıklarında yapılmaya çalışılmış, ancak düzeneğin hazırlığı esnasında kontrolsüz olarak patlaması ile saldırı gerçekleştirilememiştir. Saldııda kullanılmak üzere patlayıcı yerleştirilen Tufan isimli yat, Ağustos 2005'de infilak etmeseydi, Louai Sakka isimli El-Kaide militanının yatı yolcu gemisinin üzerine sürerek patlatmayı planladığı anlaşılmıştır. ${ }^{41}$

$\mathrm{Bu}$ dönemde terör örgütlerinin patlayıcı yüklü teknelerle yaptı̆̆ 1 saldırıların artmış olduğu görülmektedir. Bu artışın bir sebebinin Sri

\footnotetext{
${ }^{36}$ Marco D. Tomasi, "Water- borne IED Threats and the Strait of Hormuz", Joint IED Defeat Organization (JIEDDO), 2009, s. 2, https://info.publicintelligence.net/ JIEDDO-Hormuz.pdf, [Erişim Tarihi: 26.01.2019].

$37 \mathrm{http}: / /$ usnhistory.navylive.dodlive.mil/2018/04/23/uss-firebolt-pc10-rememberingheroic-coastal-patrol-ship-sailors-and-looking-forward-to-our-future/, [Erişim Tarihi: 26.01.2019].

${ }^{38}$ İngiliz BBC Haber Sitesi, "Bomb caused Philippine ferry fire", http://news.bbc.co.uk/ 2/hi/asia-pacific/3732356.stm, [Erişim Tarihi: 26.01.2019].

${ }^{39}$ Peter Chalk, The Maritime Dimension of International Security Terrorism, Piracy, and Challenges for the United States, RAND Project Air Force, California, 2008, s. 51.

${ }^{40}$ Murphy, Ibid., p. 4.

${ }^{41}$ Martin, Ibid., p. 13.
} 
Deniz Ortamında El Yapımı Patlayıcı Düzenek (EYPD)'ler Genelinde

Terörist Tehditler ve Deniz Güvenliğine Etkileri

Lanka'da uzun yıllar faaliyet gösteren ve Tamil Kaplanları (The Liberation Tigers of Tamil Eelam-LTTE) olarak anılan terör örgütü olduğu bilinmektedir. $\mathrm{Bu}$ örgütün Deniz Kaplanları olarak bilinen deniz yapılanması, 1990'lı yılların başından 2010 yılına kadar, birçok hedefine ulaşmış "Denizel EYPD" saldırıları gerçekleştirmiştir. ${ }^{42}$ Deniz Kaplanları o dönemde "herhangi bir ülkeye bağlı olmayan dünyanın en iyi yapılanmış ve en karmaşık denizci terör örgütü”,43 olmakla birlikte gerçekleştirdikleri birçok "Denizel EYPD” saldırısıyla da isimlerini duyurmuştur.

Deniz Kaplanlarının, Sri Lanka Deniz Kuvvetlerine karşı uyguladıkları taktikler sadece süratli bot saldırıları ile sınırlı kalmamıştır. Örgüt militanları kendi imkanları ile yaptıkları cep denizaltıları ile intihar saldırıları gerçekleştirmişlerdir. ${ }^{44}$ Her ne kadar cep denizaltılarının imkân ve kabiliyetleri hakkında herhangi bir bilgiye rastlanamamışsa da Sri Lanka Deniz Kuvvetlerinin ele geçirdikleri örneklerden örgütün ne denli geniş imkanlara sahip olduğunu anlamak mümkündür. ${ }^{45}$ Bugüne kadar Tamil Kaplanları hariç hiçbir terör örgütü bu ölçekte bir yeteneğe sahip olmamış veya bu tarz bir girişimde bulunmamıştır. ${ }^{46}$

Deniz Kaplanlarının kullandığı yöntemler içinde radara yakalanmayan (stealth) süratli (50-60 knot) teknelerin patlayıcı ile yüklenip gemilere saldırması sonucu, Sri Lanka Deniz Kuvvetlerine ait birçok yüzer unsur hasar almış veya batmıştır. Tamil Kaplanları, bu saldırı yönteminden El-Kaide'nin esinlendiği konusunda USS Cole ve MV Limburg saldırılarından sonra açıklamalarda bulunmuştur. El-Kaide ile Tamil Kaplanları arasında bir irtibatın olduğu teyide muhtaç ${ }^{47}$ olsa

\footnotetext{
${ }^{42}$ Tomasi, Ibid., p. 3.

${ }^{43}$ Sudha Ramachandran, "The Sea Tigers of Tamil Eelam," Asia Times, 31 August 2006, http://www.atimes.com/atimes/South_ Asia/HH31Df01.html, [Erişim Tarihi: 26.01.2019].

${ }^{44}$ Tomasi, Ibid., p. 4.

${ }^{45}$ Ayrıntılı bilgi için, Birleşmiş Milletler Mülteciler Yüksek Komiserliği Resmi İnternet Sitesi, https://www.refworld. org/docid/469f38e0c.html. (Erişim Tarihi: 30.04.2020)

${ }^{46}$ Martin, Ibid., p. 16.

${ }^{47}$ Tomasi, Ibid., p. 4.
}

\section{9}

Güvenlik Stratejileri

Cilt: 16

Say1: 34 
360

Güvenlik Stratejileri

Cilt: 16

Say1: 34

da terör örgütlerinin birbirlerinin, hedefine ulaşmış saldırılarından örnek aldıkları bir gerçektir. Nitekim intihar bombacılarının kullandığı yelek düzeneklerinin ve kadın intihar bombacısı kullanımının, ElKaide'nin Tamil Kaplanlarından örnek aldığı yöntemler oldukları bilinmektedir. $^{48}$

"Denizel EYPD" saldırısı olarak Tamil Kaplanlarının kullandığı bir diğer yöntem ise SCUBA (Self Contained Underwater Breathing Apparatus) veya kapalı devre dalış cihazı kullanan dalgıçlar olmuştur. Deniz Kaplanları 2008 yılında bu yöntemle, Sri Lanka Deniz Kuvvetlerine ait limanda bulunan bir lojistik gemisi olan MV Invincible batırmışlardır. Gemi karinasının altında gerçekleşen patlama sonrasında Sri Lanka Deniz Kuvvetleri'nin yaptığı incelemelerde, gemi enkazının yakınında SCUBA teçhizatı kuşanmış yarım bir insan cesedinin bulunmuş olması saldırının su altı intihar bombacısı tarafından yapıldığını doğrulamıştır. ${ }^{49}$ Deniz Kaplanlarının dalgıç militanları ile su altı tahrip timlerinin bağlı bulunduğu "Black Sea Tiger" olarak bilinen birim, özel olarak aldıkları dalış eğitimleri ve ellerimde bulundurdukları sualtı vasitalarıyla "su altı intihar bombacısı" olarak eylemlerde bulunmuşlardır. ${ }^{50}$

El-kaide'nin de sualtı intihar bombacısı yetiștirme üzerine çalışmalar gerçekleştirdiği, Hollanda Eindhoven'da bulunan bir dalış kursunda eğitim gören 3 kişinin, Hollanda İstihbarat Servisi tarafindan takibe alınıp yakalanmasından sonra ortaya çıkmıştır. Aynı dönemde yakalanan El-kaide militanlarının sorgularından, örgütün birçok dalış ekipmanı tedarik ettiği ögrenilmiştir. ${ }^{51}$ Yine bu dönemde Malezya'da bulunan bir dalış kursu sahibinin, tıpkı 11 Eylül saldırılarını gerçekleştiren pilotların, aldıkları kursta uçağı yere indirme kısmıla ilgilenmediği gibi,

\footnotetext{
${ }^{48}$ Revill, Ibid., p. 48.

${ }^{49}$ Ruth Doherty, "Detect and Defeat Waterborne Improvised Explosive Devices (WBIEDs)," http://www.dhs.gov/xlibrary/assets/st_detect_and_defeat_waterborne_ ied_cied.pdf, [Erişim Tarihi: 26.01.2019].

${ }^{50}$ Malaka Chandradasa, Learning from Our Enemies: Sri Lankan Naval Special Warfare against the Sea Tigers, Combating Terrorisim Exchange, Vol.2 No.2, 2012, 1-8, p. 8.

${ }^{51}$ Lorenz, Ibid., p. 18.
} 
Deniz Ortamında El Yapımı Patlayıcı Düzenek (EYPD)'ler Genelinde Terörist Tehditler ve Deniz Güvenliğine Etkileri

birkaç öğrencisinin dalış ile alakalı dekomprasyon (derinliğe bağlı dalış zamanlaması) usulleri ile ilgilenmediklerini rapor etmiştir. Bunun üzerine artan su altı intihar bombacısı tehdidine yönelik olarak Amerikan Federal Soruşturma Bürosu (FBI), Profesyonel Dalış Eğitmenleri Birliği'nden (Professional Association of Diving Instructors-PADI), 2002 yılında son 3 yılda dalış eğitimi gören iki milyona yakın kişinin bilgisini alarak incelemiştir. ${ }^{52}$

"Denizel EYPD" lerin hedefleri sadece askeri gemiler ile sinırlı değildir. Terör örgütlerinin, siyasi hedeflerine ulaşmak için özellikle deniz ulaşıırma yollarının düğüm noktalarına yönelik saldırılar planladığı görülmüştür. Bu saldırılardan bir tanesi 2010 yılında Hürmüz Boğazı'nda Marshal Adaları bayraklı Japonya'ya ait MV-M Star tankerini hedef almıştır. Saldırı ile alakalı Birleşik Arap Emirlikleri'ne bağlı uzmanların yürüttüğü soruşturma neticesinde, geminin hasar alan sancak tarafinda patlayıcı kalıntılarına rastlanılmıştır. Uzmanların raporda belirttiği görüşlere göre tankerin patlayıcı yüklü bir bot saldırısına uğramış olabileceği düşüncesi, o dönemde El-kaide bağlantılı "Abdullah Azzam Tugayları" tarafından saldırının üstlenilmesi ile gerçeklik kazanmıştır. ${ }^{53}$

El-kaide'nin Pakistan yapılanmasının 6 Eylül 2014 tarihinde Karaçi Limanı'ndaki PNS Zulfiqar firkateynine düzenlendiği saldırı halen birçok soru işareti barındırmakta ancak, yetkililerin olay ile alakalı titiz bir soruşturma yürüttükleri bilinmektedir. Olay tarihinde medyada yer alan haberlere göre, saldırıya katılanlar arasında Pakistan Deniz Kuvvetleri'nde görevli personelin bulunduğu ve bu kişilerin yardımıyla gerçekleşen saldırıda biri gemi personeli üç kişinin hayatını kaybettiği bilinmektedir. ${ }^{54}$ PNS Zulfiqar firkateyninde daha önce görev yapmış silah subayının, örgüt tarafından ideolojik baskı ve beyin yıkama yöntemleriyle saldırıya içerden destek vermesi neticesinde,

\footnotetext{
${ }^{52}$ Lorenz, Ibid., p. 19.

${ }^{53}$ Martin, Ibid., p. 14.

54 "PNS Zulfiqar Attack Five Navy Officers Get Death Penalty", Pakistan Exprerss Tribune, https://tribune.com. pk/story/1110057/pns-zulfiqar-attack-five-navy-officersget-death-penalty/, [Erişim Tarihi: 26.03.2019].
}

361

Güvenlik Stratejileri

Cilt: 16

Say1: 34 
362

Güvenlik Stratejileri

Cilt: 16

Sayı: 34

teröristlerin zorlanmadan gemiye girdikleri ve asıl amaçlarının gemiyi ele geçirerek Hint Okyanusu'nda bulunan Amerikan Deniz Kuvvetleri unsurlarına saldırmak olduğu öğrenilmiştir. Gemide görevli nöbetçi personelin dikkati üzerine tespit edilen teröristleri etkisiz hale getirmek maksadıyla, Pakistan Deniz Kuvvetleri Özel Birlikleri gemiye girmiş ve durumu kontrol altına almışlardır. Gemide yaşanan çatışmalar esnasında, son teröristin kendini boş bir kamaraya kilitleyerek üzerindeki düzeneği infilak ettirmesi sonrası tüm teröristler etkisiz hale getirilmiştir. Teröristlerin çantalarında yapılan aramalarda yanlarında büyük asma kilitler bulunmuş ve amaçlarının gemi personelini toplu olarak kamara ve salonlara kilitleyerek etkisiz hale getirmek olduğu anlaşılmıştır. Saldırı tarihinden hemen sonra PNS Zulfiqar firkateyninin Hint Okyanusu'nda görev yapan NATO Birleşik Görev Kuvveti 150'nin emrine girecek olmas ${ }^{55}$, El-kaide tarafindan hedef alınmasının temel sebebi olarak gösterilmektedir.

Ülkemizde "Denizel EYPD" olarak yakın dönemde karşılaşılan bir vaka, Hatay'ın Samandağ ilçesindeki Çevlik Limanı'ndan denize açılan balıkçıların bir ihbarı üzerine yaşanmıştır. 23 Mayıs 2016 tarihinde limandan yaklaşık dört kilometre açıta, içinde iki kişinin cesedinin bulunduğu bir can salının balıkçılar tarafından Sahil Güvenlik Komutanlığına rapor edilmesi üzerine, bölgeye ekipler sevk edilmiştir. Can salının içindeki kişilerin hayatta olmadığı anlaşıldıktan sonra, savcının talimatı ile can salının limana getirilmesi istenmiştir. Sahil Güvenlik ekiplerinin can salını halat ile yedekleyerek sahile getirmeye çalıştığ 1 esnada yaşanan patlama neticesinde bir Sahil Güvenlik Eri hayatını kaybetmiş ve iki kişi yaralanmıştır. Yapılan incelemelerde, can salının Suriye kıyılarından geldiği ve asıl hedefin sala çıkması beklenen Sahil Güvenlik Komutanlığı personeli olduğu anlaşılmıştır. ${ }^{56}$

2011 Ocak ayından itibaren, Orta Doğu ve Kuzey Afrika

${ }^{55}$ Sinan Topuz, Modern Deniz Harbini ve Denizler İçin Mücadeleyi Anlamak, Alibi Yayıncilık, Ankara, 2016, s. 393.

${ }^{56}$ Hürriyet Gazetesi, http://www.hurriyet.com.tr/gundem/hatayda-teknede-patlama-1sehit-40107334, [Erişim Tarihi: 30.01.2019]. 
Deniz Ortamında El Yapımı Patlayıcı Düzenek (EYPD)'ler Genelinde

Terörist Tehditler ve Deniz Güvenliğine Etkileri

ülkelerinde yaşanan rejim karşıtı halk hareketleri Yemen'de de etkisini göstermiştir. Eski Cumhurbaşkanı Ali Abdullah Saleh taraftarları ile Husilerin kurduğu ittifak, ülkede BM destekli Ulusal Diyalog Konferansı'nın başlatmış olduğu yeni anayasa yazım sürecine karşı çıkmış ve yönetime el koymuştur. Yaşanan gelişmeler neticesinde Suudi Arabistan'ın öncülüğünde ve bazı Arap ülkelerinin katılımıla oluşturulan koalisyon, 25 Mart 2015 tarihinden itibaren Husi-Saleh güçlerine karşı askeri operasyon başlatmıştır. ${ }^{57}$ Ülkede süren çatışmaların devem ettiği dönemde, Husilerin, Suudi Arabistan Deniz Kuvvetlerine ait Al-Madinah (RSN 702) firkateynine düzenledikleri "Denizel EYPD" saldırısı dikkat çekmiştir.

Husiler tarafından Yemen'in Al-Hudaydah limanı açılarında 31 Ocak 2017 tarihinde gerçekleştirilen saldırıda kullanılan, insansız bomba yüklü süratli botun, Al-Madinah firkateynine helikopter platformu mevkiinden çarpması neticesinde, iki gemi personeli hayatını kaybetmiş ve üç personel yaralanmıştır. Suudi yetkililer tarafindan yapılan açıklamalarda; saldırı için üç adet uzaktan komutalı bomba yüklü süratli botun kullanıldığı, iki botun Al-Madinah tarafından tespit edildiği ancak, üçüncü botun gemiye çarptığı belirtilmiştir. ${ }^{58}$ Saldırı sonrası ABD'nin Bahreyn'de bulunan 5'inci Filosu ve aynı zamanda ABD Deniz Kuvvetleri Merkez Kuvvetler Komutanı olan Koramiral Kevin Donegan tarafından yapılan açıklamalarda; saldırının Kızıl Deniz'de bulunan Arap koalisyonuna karşı Husiler tarafından gerçekleştirilen bir saldırı olduğu ancak, saldırıda kullanılan uzaktan kumandalı süratli botları, Husilerin kendi imkanları ile geliştirmiş olamayacağı ve Husilerin bu konuda kuvvetle muhtemel İran tarafindan desteklendiklerini bildirmiştir. ${ }^{59}$ Konu kapsamında Koramiral Donegan,

\footnotetext{
${ }^{57}$ Türkiye Cumhuriyeti Dışişleri Bakanlı̆̆ http://www.mfa.gov.tr/yemen-siyasi-gorunumu.tr.mfa, [Erişim Tarihi: 30.01.2019].

58 "RSN Al Madinah (Saudi Arabia)", http://www.wbied.com/case-studies/rsn-almadinah-saudi-arabia/, [Erişim Tarihi: 30.01.2019].

${ }^{59}$ Christopher P. Cavas, "New Houthi weapon emerges: a drone boat", https://www.defensenews.com/digital-show-dailies/idex/2017/02/19/new-houthi-
}

363

Güvenlik Stratejileri

Cilt: 16

Say1: 34 
364

Güvenlik Stratejileri

Cilt: 16

Sayı: 34

İran Devrim Muhafizları Ordusu'nun envanterinde bulunan "Ya Madhi" sınıfı insansız deniz araçlarını ima ederek, yapılan saldırıların deniz ortamında isyancı kuvvetler tarafindan gerçekleştirilen ilk insansız uzaktan komutalı bot saldırısı olduğunu vurgulamıştır. ${ }^{60}$

Kızıldeniz'de 2018 yılı ocak ayında rapor edilen şüpheli bir olayda, yine Al-Hudaydah bölgesinde bulunan ticari bir gemiye 3 adet şüpheli botun yaklaştığı fakat botlardan ikisinde insan bulunurken birinin insansız olduğu tespit edilmiştir. Bölgede denetimlerini sıklaştıran Arap Koalisyonu güçlerinin ele geçirdiği 10 metrelik devriye botu benzeri bir deniz vasitasında yapılan incelemelerde; botun kumanda kollarına bağlı bulunan bir uzaktan kumanda sistemi ile uzaktan komuta edilebilir hale getirildiği ve Sovyetler Birliği döneminden kalma gemilere karşı kullanılan harp başlıklarının patlayıcı yükü olarak kullanıldığı belirlenmiştir. $^{61}$

USS Cole saldırısından günümüze kadar gerçekleştirilmiş önemli "Denizel EYPD" saldırılarının bir tablo halinde gösterilmesinin faydalı olacağı değerlendirilerek aşă̆ıda sunulmuştur.

weapon-emerges-a-drone-boat/, (19.02.2017), [Erişim Tarihi: 30.01.2019].

60 "Drone Boat Was Used in Saudi Frigate Attack", https://www.maritimeexecutive.com/article/drone-boat-used-to-strike-saudi-frigate, [Erişim Tarihi: 30.01.2019].

61 "Water Borne Improvised Explosive Devices (WBIED)", SOLACE Global Maritime Advisory Report, 8 March 2018, , s. 4, https://www.solaceglobal.com/wp-content/ uploads/2018/03/20180308-Maritime-Advisory-History-and-Usage-of-Water-BorneImprovised-Explosive-Devices-1.pdf, [Erişim Tarihi: 30.01.2019]. 
Deniz Ortamında El Yapımı Patlayıcı Düzenek (EYPD)'ler Genelinde

Terörist Tehditler ve Deniz Güvenliğine Etkileri

Tablo 1. Önemli "Denizel EYPD” Saldırıları

\begin{tabular}{|c|c|c|c|c|c|}
\hline Tarih & Bölge & $\begin{array}{c}\text { Denizel } \\
\text { EYPD Türü }\end{array}$ & $\begin{array}{c}\text { Saldırıyı } \\
\text { Gerçekleştiren } \\
\text { Örgüt }\end{array}$ & $\begin{array}{c}\text { Hedef Alınan } \\
\text { Unsur }\end{array}$ & $\begin{array}{c}\text { Ölü } \\
\text { Sayısı }\end{array}$ \\
\hline 12.10 .2000 & $\begin{array}{l}\text { Aden/ } \\
\text { Yemen }\end{array}$ & Süratli Bot & El-Kaide & USS Cole & 17 \\
\hline 06.10 .2002 & $\begin{array}{l}\text { Aden/ } \\
\text { Yemen }\end{array}$ & Süratli Bot & El-Kaide & MV Limburg & 3 \\
\hline 2004 & $\begin{array}{c}\text { Basra } \\
\text { Körfezi }\end{array}$ & Süratli Bot & $\begin{array}{c}\text { Tevhit } \\
\text { ve Cihat } \\
\text { Cemaati }\end{array}$ & $\begin{array}{c}\text { Khor Al-Amaya } \\
\text { ve Al Basra Petrol } \\
\text { Tesisleri }\end{array}$ & - \\
\hline 24.04 .2004 & $\begin{array}{c}\text { Basra } \\
\text { Körfezi }\end{array}$ & $\begin{array}{c}\text { Balıkçı } \\
\text { Teknesinde } \\
\text { bulunan }\end{array}$ & $\begin{array}{c}\text { Tevhit } \\
\text { ve Cihat } \\
\text { Cemaati }\end{array}$ & $\begin{array}{c}\text { USS Firebolt } \\
\text { PC } 10\end{array}$ & 3 \\
\hline 04.08 .2005 & $\begin{array}{l}\text { Antalya } \\
\text { Körfezi }\end{array}$ & $\begin{array}{l}\text { Tufan Yatına } \\
\text { yüklenen } \\
\text { EYPD }\end{array}$ & El-Kaide & $\begin{array}{c}\text { Yolcu Gemisi } \\
\text { (İsrail ve ABD } \\
\text { vatandaşları) }\end{array}$ & - \\
\hline 2004 & Filipinler & $\begin{array}{l}\text { Televizyon } \\
\text { içerisindeki } \\
20 \text { dinamit }\end{array}$ & $\begin{array}{c}\text { Ebu Seyyaf } \\
\text { Grubu }\end{array}$ & Super Ferry 14 & 116 \\
\hline 25.03 .2006 & Sri Lanka & Süratli Bot & $\begin{array}{c}\text { Tamil } \\
\text { Kaplanları }\end{array}$ & Karakol Gemisi & 8 \\
\hline 2006 & Sri Lanka & Süratli Bot & $\begin{array}{c}\text { Tamil } \\
\text { Kaplanları }\end{array}$ & $\begin{array}{l}\text { Askeri Nakliye } \\
\text { Gemisi }\end{array}$ & 17 \\
\hline 2006 & Sri Lanka & Süratli Bot & $\begin{array}{c}\text { Tamil } \\
\text { Kaplanları }\end{array}$ & Karakol Gemisi & 1 \\
\hline 2007 & Sri Lanka & $\begin{array}{c}\text { Geliştirilmiş } \\
\text { Deniz Mayını }\end{array}$ & $\begin{array}{c}\text { Tamil } \\
\text { Kaplanları }\end{array}$ & Karakol Gemisi & - \\
\hline 2008 & Sri Lanka & İntihar Dalgicı & $\begin{array}{c}\text { Tamil } \\
\text { Kaplanları }\end{array}$ & $\begin{array}{c}\text { A-520/MV } \\
\text { Invincible }\end{array}$ & 1 \\
\hline
\end{tabular}

365

Güvenlik Stratejileri

Cilt: 16

Say1: 34 
366

Güvenlik Stratejileri Cilt: 16

Sayı: 34

\begin{tabular}{|c|c|c|c|c|c|}
\hline 2010 & $\begin{array}{c}\text { Hürmüz } \\
\text { Boğazı }\end{array}$ & Süratli Bot & $\begin{array}{c}\text { Abdullah } \\
\text { Azzam } \\
\text { Tugayları }\end{array}$ & MV-M Star & - \\
\hline 23.05.2016 & $\begin{array}{c}\text { Hatay } \\
\text { Samandağı }\end{array}$ & $\begin{array}{c}\text { Can salına } \\
\text { tuzaklanan } \\
\text { EYPD }\end{array}$ & Bilinmiyor & $\begin{array}{c}\text { Türk Sahil Güvenlik } \\
\text { Komutanlığ } \\
\text { Personeli }\end{array}$ & 1 \\
\hline 31.01 .2017 & $\begin{array}{c}\text { Al- } \\
\text { Hudaydah }\end{array}$ & $\begin{array}{c}\text { İnsansız } \\
\text { Süratli Bot }\end{array}$ & Husi İsyancılar & $\begin{array}{c}\text { RSN 702 Al- } \\
\text { Madinah }\end{array}$ & 2 \\
\hline
\end{tabular}

Tablo-1 USS Cole Saldırısı Sonrası Yaşanan Önemli Denizel EYPD Saldırıları ${ }^{62}$

Yapılan araştırmalar neticesinde, geçmiş dönemde deniz ortamında hedefine ulaşmış saldırılar gerçekleştiren terör örgütlerinin:

- İrlanda Halk Kurtuluş Örgütü (Irish People's Liberation Organisation-PIRA)

- Filistin Kurtuluş Cephesi,

- İslam Cemaati Örgütü (Al-Gama'a al-Islamiyya-Mısır),

- Ebu Seyyaf Grubu, (Filipinler)

- Tamil Kaplanları, (Sri Lanka)

- Tevhit ve Cihat Cemaati (Jama'at al-Tawhid wal-Jihad)

- El-Kaide

olduğu tespit edilmiştir. ${ }^{63} \mathrm{Bu}$ örgütlerden halen aktif olarak saldırılarına devam eden El-kaide'nin deniz ortamına yönelik son saldırısının, Karaçi Limanı'nda bulunan PNS Zulfiqar firkateynine yapıldığı bilinmektedir. Bu saldırı özelinde El-kaide'nin daha önce gerçekleştirdiği hedefine ulaşmış saldırıların mimarı olan Nashiri'nin belirlediği yöntemler içerisine bir yenisinin eklendiği görülmektedir. PNS Zulfıqar firkateynine yapılan saldırı başarıya ulaşmış olsaydı,

62 "Water Borne Improvised Explosive Devices (WBIED)", SOLACE Global Maritime Advisory Report, p. 5.

${ }^{63}$ Michael D. Greenberg ve diğ., Maritime Terrorism Risk and Liability, RAND Corporation, California, 2006, p. 19. 

sistemlerinin içerden destek alınmadan kullanılamayacağını bilen terör örgütü, bu problemi ideolojik olarak kendine bağladığı muvazzaf ve emekli deniz subayları ile çözmeye çalışmıştır. ${ }^{64}$ Ancak, Pakistan Deniz Kuvvetleri'nin zamanında teröristleri etkisiz hale getirmesi sonucu, saldırı başarısız olmuştur.

Yemen'de devam eden iç karıșıklıkların bir sonucu olarak Husiler tarafindan 2017 yılında El Madinah firkateynine gerçekleştirilen saldırıda, ilk defa insansız uzaktan komutalı bomba yüklü süratli botun kullanılmış olması, son dönemde karşılaşılan en önemli "Denizel EYPD" olayıdır. Terör örgütlerinin intihar eylemleri için militan bulmasının her geçen gün zorlaştı̆̆ göz önüne alındığında, ilerleyen dönemlerde bu tarz insansız saldırı yöntemlerinin kullanımının artacağı söylenebilir. Saldırı ile alakalı yapılan değerlendirmelerde İran'ın Husilere destek verdiği açık olarak belirtilmekte ve İran envanterinde bulunan İnsansız Su Üstü Araçları'nın (ISA) bu kapsamda kullanılabileceğine dair çıkarımlar yapılmaktadır.

Husiler tarafindan Yemen açıklarında düzenlenen saldırılar sadece insansız uzaktan komutalı botlar ile sınırlı kalmamıştır. Yakın dönemde Kızıldeniz'in güneyinde yer alan Yemen limanlarının birçoğunda deniz mayınları sebebiyle balıkçı tekneleri batmış ve Yemen Sahil Güvenlik unsurları hasar almıştır. Bab-El Mandeb Boğazı'na yaklaşık 40 deniz mili mesafede yer alan Yemen'in Mocha Limanı açıklarında, Yemen Sahil Güvenliğine ait bir devriye botunun bahse konu mayınlara çarpması sonucu, iki personel hayatını kaybetmiş, sekiz personel ise yaralanmış olup, Husiler tarafından yapılan bahse konu saldırılarda, basit fabrikasyon kontak mayınlarla birlikte el yapımı deniz mayınları

${ }^{64}$ Wall Street Journal, https://www.wsj.com/articles/al-qaeda-militants-tried-to-seizepakistan-navy-frigate-1410884514 [Erişim Tarihi: 31.03.2020]. 
kullanılmıştır. ${ }^{65}$ Yakın dönemde Suudi Arabistan gemileri başta olmak üzere diğer koalisyon gemilerine karşı Husiler tarafindan, karadan atılan güdümlü mermiler kullanılmış ve hedefine ulaşmış saldırılar gerçekleştirilmiştir. Husilerin destekleyicisi olarak nitelenen İran'ın envanterinde bulunan deniz mayınlarının ve gemilere karşı karadan atılan güdümlü mermilerin çeşitliliği göz önüne alındığında bölgede tehdit giderek artmaktadır. Yemen'de süren iç karışıklık sebebiyle bölgede çok kontrolsüz bir şekilde insansız hava araçları, kara saldırı füzeleri ile hafif silah trafiğinin yaşandığı raporlarda geçmektedir. ${ }^{66} \mathrm{Bu}$ tehditlerin, en önemli deniz trafik rotalarından biri olan Kızıldeniz'e yakın bir alanda yaşanması, ticari deniz trafiği üzerinde olumsuz etkilerinin olabileceği sebebiyle yakından takip edilmeli ve gerekli önlemler alınmalıdır.

\section{Denizel EYPD Tehdidine Karşı Alınabilecek Tedbirler}

Bir önceki bölümde incelen "Denizel EYPD" saldırıları genel olarak değerlendirildiğinde, karşımıza bugün itibarıyla çıkması beklenen en büyük tehdidin patlayıcı yüklü süratli botlar olduğu anlaşılmaktadır. Başta Tamil Kaplanları ve El-Kaide olmak üzere birçok terör örgütünün bu tarz saldırılarda, öncelikli olarak insanları kullandığı ve botlar ile birlikte gemilere karşı intihar saldırıları düzenledikleri görülmektedir. Ancak, Husiler tarafından Yemen sularında düzenlenen insansız uzaktan komutalı bomba yüklü süratli bot saldırıları, karşılaşılan "Denizel EYPD" olayını daha karmaşık hale getirmektedir.

Öncelikle üzerinde durulması gereken husus bahse konu bomba yüklü botların süratleridir. Husiler tarafindan kullanılan süratli botların 50-60 deniz mili gibi çok yüksek süratlerde seyretmeleri ve küçük

65 "Saudi Forces Find More Naval Mines Off Yemen", https://www.maritimeexecutive.com/article/saudi-forces-find-more-naval-mines-off-yemen, [Erişim Tarihi: 23.02.2019].

66 BM Güvenlik Konseyi, Yemen Uzmanlar Panel Raporu, 27 Ocak 2020, https://reliefweb.int/report/yemen/letter-dated-27-january-2020-panel-experts-yemenaddressed-president-security-council (ErişimTarihi: 28. 03. 2020) 
radar kesit alanları sebebiyle gemiler tarafından su üstü radarları ile tespit edilebilmelerini zorlaştırmaktadır. $\mathrm{Bu}$ tarz saldırıların genel itibarıyla karadan yönlendirileceği düşünülse de açık deniz ortamında da bir ana gemi vasitasıyla bu tarz saldırıların yapılması ihtimali mevcuttur. İSA teknolojilerindeki gelişmeler ile birlikte birçok ülke deniz kuvvetleri envanterine bu araçları katmaktadır. ISA'ların taarruz maksatlı kullanımının yakın gelecekte dünya donanmaları tarafından taktiksel manada bir harekâta dönüşme olasılığ Bununla birlikte bu araçların asimetrik tehdit unsuru olarak terör örgütleri tarafindan kötü amaçlı kullanılmaları muhtemeldir. Manevra alanı olarak yeterli sahanın bulunmadığ dar boğazlarda ve kritik geçitlerde, savaş gemileri dahi sürü halinde saldıran İSA'lara karşı savunmasız kalabilecektir. Bu kapsamda gemilerin yakın savunma silahlarının önemli olacağı ve bu tarz saldırılara karşı kullanılabilecek etkili silahların geliştirilmesi gerekli görülmektedir.

Her ne kadar bugüne değin deniz vasıtalarına karşı somut bir saldırıda kullanılmış olmasalar da İnsansız Hava Araçlarının (İHA) veya diğer adıyla "Dronların" bu kapsamda kullanılması beklenen bir diğer tehdit olacağı açıktır. 10 Kasım 2018 tarihinde Şırnak ilinde, 10 Kasım Anma Törenlerine ve askeri birliklere PKK tarafından gerçekleştirilen dron saldırılarında; sekiz adet model uçak tarzı dron kullanıldığ 1 ve bahse konu dronlardan bazılarının intihar saldırısında bulunurken bazılarının ise taşıdıkları düzenekleri bırakarak geri kaçtığ açık kaynaklarda yer almıştır. ${ }^{67}$ Herhangi bir can kaybının yaşanmadığı saldırılar sonrası yapılan incelemelerde, dronların Irak'1n kuzeyinde yaklaşık $45 \mathrm{~km}$ mesafede yer alan bir bölgeden kontrol edildiği, teröristlerin bu eğitimleri Mahmur kampında aldıkları ve dronların yaklaşık iki $\mathrm{kg}$ kadar bir yük taşıyabildikleri bilgisi medyada yer almıştır. $^{68}$

\footnotetext{
67 “Teröristler Şırnak’ta 8 model uçakla saldırı düzenledi”, https://www.haberturk.com/teror istler-sirnak-ta-8-model-ucakla-saldiri-duzenledi-2216071, [Erişim Tarihi: 23.02.2019].

68 "PKK'nın gizli drone üssü", https://www.cnnturk.com/turkiye/pkknin-gizli-droneussu, [Erişim Tarihi: 23.02.2019].
}

369

Güvenlik Stratejileri

Cilt: 16

Say1: 34 
ABD Deniz Kuvvetleri'ne ait gemilere Kızıldeniz ve Hürmüz

Güvenlik Stratejileri

Cilt: 16

Sayı: 34
Boğazı bölgelerinde yakın mesafeden dron tacizlerinde bulunulduğu bilinmektedir. Bu tarz saldırıların gelişen dron teknolojileri ile birlikte önemli bir sorun yaratacağından hareketle, ABD Deniz Kuvvetlerinin hem yüzer hem kıyı birliklerinin dronlara karşı tedbirler aldıkları belirtilmektedir. ABD Deniz Kuvvetleri dronlar ile mücadele edebilmek için geliştirilmiş Hafif Deniz Hava Savunma Entegre Sistemi (LMADIS-Light Marine Air Defense Integrated System) olarak bilinen birleştirilmiş bir dron savar sistemini, Kızıldeniz, Süveyş Kanalı ve Hürmüz Boğazı gibi kritik bölgelerde, değerli birliklerin üzerine konuşlandırarak kullanmaya başlamıştır. LMADIS sisteminin gemiler üzerine gelebilecek dronları emniyetli mesafeden tespit ve teşhis ettiği, müteakiben elektronik olarak zararsız hale getirdiği bilgisi açık kaynaklarda yer almaktadır. ${ }^{69}$ Benzer bir sistem Türkiye'de bir firma tarafindan geliştirilmiştir. Bahse konu bu dron savar sistemi $2,5 \mathrm{~km}$ ye kadar dronları tespit edebilmekte ve $500 \mathrm{~m}$ mesafeden lazer vasitasiyla dronları imha edebilmektedir. ${ }^{70}$ Ancak, unutulmamas1 gereken bir husus saldırıların sürüler halinde hareket eden dronlar tarafindan yapılabileceğidir. $\mathrm{Bu}$ kapsamda dron savar sistemlerinin sürü halinde saldırılara karşı etkinliğinin arttırılması çalışmalarına devam edilmeli ve farklı yönlerden gelebilecek sürü halinde saldırılara karşı gemilerin ve personelin hazırlıklı bulunması gerekmektedir.

Denizde seyir halinde bulunan gemiler için bir diğer önemli tehdit mayınlardır. Çalışmada daha önce belirtildiği şekilde terör örgütleri, ele geçirdiği fabrikasyon deniz mayınlarının yanı sıra, kendi imal edebilecekleri mayın benzeri düzenekleri çeşitli kamuflaj yöntemleri ile etkili bir şekilde kullanabilirler. Deniz üzerinde yüzen şüpheli

\footnotetext{
${ }^{69}$ Shawn Snow, "Here's why the Corps strapped a counter-drone system to the deck of a warship in the Suez Canal", https://www.marinecorpstimes.com/news/your-marinecorps/2019/01/31/the-corps-strapped-a-new-counter-drone-system-to-the-deck-of-awarship-transiting-the-suez-canal-heres-why/, [Erişim Tarihi: 27.03.2019].

${ }^{70}$ Meteksan Kapan Dron Savar Sistemi, http://www.meteksan.com/media/file/kapandrone-savar-sistemi-brosur_1532350611.pdf, [Erişim Tarihi: 27.03.2019].
} 
cisimlerin her zaman bu kapsamda değerlendirilmesinin ve gerekli tedbirlerin alınması oldukça önem arz etmektedir. Deniz ortamında karşılaşılması olağan görülen çöp torbası, bidon, kütük vb. cisimlerin bir "Denizel EYPD" olma olasılığı her zaman bulunmaktadır. Bu kapsamda, seyir esnasında karşılaşılan bu tarz cisimlere şüphe ile yaklaşılmalı ve mümkün olduğu kadar uzak mesafeden tespit ve teşhis edilerek gerekli önlemler alınmalıdır.

Yabancı ülke limanlarında bulunan Deniz Kuvvetleri unsurlarının olası "Denizel EYPD" saldırılarına karşı gerek su altı gerek su üstü kuvvet koruma tedbirlerine titizlikle riayet etmesi gerekmektedir. İskele veya gemi karinasına koyulabilecek bir "Denizel EYPD" nin tespit edilebilmesi maksadıyla gerekli dalış ve kontrol faaliyetlerinin, gayri muayyen zamanlarda yapılması önemlidir. Günümüzde, savaş yüzücülerinin ve su altı tahrip timlerinin imkân kabiliyetleri ile sualtından saldırı yeteneğine sahip Tamil Kaplanları benzeri bir örgüte rastlanılmamış olsa da, SCUBA veya kapalı devre dalış ekipmanlarını tedarik edebilmeleri oldukça kolaydır. Bu noktadan hareketle, gemi etrafında rüzgâr üstü mevkilerde ve bölgedeki akıntı durumuna göre; devriye botu kullanımı ve bu tarz bir saldırıda gemi karinasına yaklaşacak yüzücüleri engellemek için gayri muayyen zamanlarda sonar ve pervanelerin çalıştırılması etkili olacaktır. Gerginlik veya harp durumunda ise gemiler etrafında görülebilecek dalgıç emarelerine (deniz yüzeyinde görülen kabarcıklar veya karaltılara) karşı küçük el şarjları atılarak müdahale edilebileceği de unutulmamalıdır.

Gemiye ziyaret maksadıyla gelen şahısların ve gemiye getirilen malzemelerin gerekli kontrollerinin yapılarak alınması gerekmektedir. Özellikle yabancı ülke limanlarında bulunan gemilerin bu kapsamda gerek ziyaretçileri gerekse gemiye gelen malzemeleri, titiz bir şekilde araması ve olası bir saldırı girişimini gemiye intikal etmeden durdurması önemlidir. Sahil makamları tarafindan oluşturulan arama ve kontrol noktalarının imkân ve kabiliyetleri gemi tarafından öğrenildikten sonra, görülen yetersizlik alanlarında kendi çözümlerini üretmek gemi personeline düşmektedir.

Yeni geliştirilmekte olan patlayıcı madde tespit sistemlerinin çok farklı özelliklere sahip olduğu bilinmektedir. Yakın dönemde 
372

Güvenlik Stratejileri

Cilt: 16

Sayı: 34

Avusturalya Kraliyet Donanması'nın, Avusturalya merkezli bir teknoloji firması ile yaptığı bir milyon Avusturalya doları tutarındaki sözleşme ile su üstü unsurlarında kullanılması maksadıyla, Taşınabilir Raman (Geliştirilmiş Patlayıc1 Detektörü-Portable Raman Improvised Explosive Detector-PRIED) projesini başlattığ 1 açık kaynaklarda yer almaktadır. ${ }^{71}$ Bahse konu PRIED detektörünün uzak mesafeden yalnızca konvansiyonel patlayıcı maddeleri değil Ev Yapımı Patlayıcılar ile Kimyasal Biyolojik Radyolojik ve Nükleer (KBRN) harp maddelerini de tespit etme özelliğine sahip olduğu belirtilmektedir. ${ }^{72}$ ABD Deniz Kuvvetleri yüzer unsurları tarafindan kullanılması maksadıyla daha küçük ve kullanımı daha kolay bir detektör tedarikine gidildiği ve 10 milyon Amerikan dolarlık bir sözleşme imzalandığı öğrenilmiştir. "SEEKERe" adı verilen detektörün test kartı üzerindeki renk değişimleri yoluyla birçok patlayıcı maddeyi ve KBRN harp maddesini tespit edebildiği bilgisi mevcuttur. ${ }^{73}$ Benzer tespit sistemlerinin, Türk savunma sanayi firmaları tarafından geliştirilmesi ve üretiminin yapılmasının, Milli Savunma Sanayiimize katkıda bulunacağı açıktır.

Deniz Güvenlik Harekâtları ve diğer denetim görevlerinde görevlendirilen Deniz Kuvvetleri unsurlarının şüpheli vasitalar üzerinde icra edecekleri boarding harekâtlarında, personelin maruz kalabileceği "Denizel EYPD" lere yönelik farkındalıklarının yüksek seviyede olması gerekmektedir. Şüpheli vasıtalara yapılacak boarding harekâtı öncesinde, varsa havadan keşif imkânlarının kullanılmasının ve ilk giriş yöntemlerinin alışılmışın dışında yöntemler vasıtasıyla Fast Rope (bir halat yardımıyla helikopterden yere hızlıca inme tekniği) vb.

71 "Defence Innovation Hub showcases maritime counter-IED tech", https://www.defenceconnect.com.au/maritime-antisub/2998-defence-innovation-hubshowcases-maritime-counter-ied-tech, [Erişim Tarihi: 27.03.2019].

72 "PRIED (Portable Raman Improvised Explosive Detector)", https://www.epequip.com/ catalogue/all-hazards-management/pried/, [Erişim Tarihi: 27.03.2019].

73 "U.S. Navy Awards DetectaChem Hand Held Explosive Detector (HHED) Contract", https://detectachem.com/?gclid=CjwKCAjwvuzkBRAhEiwA9E3FUIUV8fSCJGMQLwi8R5suJVhrILujwJenYyBsG0X_aAM9b6QmKSawRoC7ykQAvD_BwE, [Erişim Tarihi: 27.03.2019]. 
Deniz Ortamında El Yapımı Patlayıcı Düzenek (EYPD)'ler Genelinde

Terörist Tehditler ve Deniz Güvenliğine Etkileri

yapılmasının personelin maruz kalabileceği riskleri en aza indirecektir. Şüpheli gemide icra edilecek müteakip arama ve emniyete alma faaliyetlerinde, potansiyel "Denizel EYPD" tehditlerinin nerelerde olabileceğine ilişkin dikkatle hareket edilmesi ve gerekli noktalarda şüpheli gemi personelinin rehberliği eşliğinde arama yapılması önemlidir.

Gerek limanlarda gerekse demir yerinde bulunan; yüksek değerlikte sivil bahriye gemileri ile deniz kuvvetleri unsurlarının, denizden gelebilecek tehditlere karşı alabileceği bir diğer emniyet tedbiri, deniz üzerinde yüzen bariyer sistemleridir. Bu sistemler temel olarak deniz üzerinde yüzen şamandıralar arasında bulunan çelik teller ile desteklenmiş fiziksel engellerdir. Birçok ulusal ve uluslararası firma tarafından değişik özelliklerde üretilen bu sistemlerin süratli botlara karş1 üretilen modellerinin, 20 metreye kadar olan ve 60 knot sürat yapan tekneleri durdurabildikleri bilgisi mevcuttur. Amerikan Deniz Kuvvetleri bu kapsamda anlaşmalı olduğu tüm tersaneler için bu tarz bariyerleri kullanma zorunluluğu getirmiş bulunmaktadır. ${ }^{74}$ Liman tesislerinin güvenliğine yönelik artan ihtiyaçlar paralelinde yeni üretilen bariyer sistemlerinin, uzaktan kumanda sistemleri ile katlanarak açılır ve kapanır hale gelebilen modelleri üretilmiştir. ${ }^{75}$ Ticari faaliyetlere sahip ve önem arz eden limanlar ile askeri olarak kullanılmakta olan yanaşma yerleri, deniz üsleri ile önemli tersanelerin bu sitemler ile güvenliklerini arttırabileceklerdir.

\section{Sonuç}

Ulusal ve uluslararası hukuka tâbî olan deniz alanlarında seyir hakkı, gemiler, altyapılar ve kaynakların emniyette olduğu sürekli durum olarak ifade edilen "Deniz Güvenliğì"nin önemini her geçen gün artmaktadır. Denizlerin artan kullanımı ile birlikte, deniz ulaştırma yollarında her gün seyreden petrol ve sıvılaştırılmış doğal gaz (LNG)

\footnotetext{
74 "Small boats, big problems: Navy blocks attacks from the sea with floating barriers", https://techlinkcenter.org/ truston -port-security/, [Erişim Tarihi: 23.02.2019].

75 "Comprehensive Maritime Barrier Solutions", https://www.halodefense.com/, [Erişim Tarihi: 23.02.2019].
}

373

Güvenlik Stratejileri

Cilt: 16

Say1: 34 
374

Güvenlik Stratejileri

Cilt: 16

Sayı: 34

taşıyan süper tankerler gibi dünya ticareti için önemli kargoların, açık deniz petrol ve doğal gaz platformlarının, deniz üzerindeki yenilenebilir enerji tesislerinin güvenliği ön plana çıkmaktadır. Bu kapsamda ABD liderliğinde; NATO, $\mathrm{AB}$ ve diğer bölgesel güvenlik örgütleri deniz ulaştırması için önemli rotalarda güvenlik ortamını oluşturabilmek için çeşitli harekatlar düzenlemektedir.

Gerek çevre denizlerimizde gerekse deniz ticaret rotalarındaki önemli güzergâhlarda, "Deniz Güvenliği" ne katk1 sağlamak ve olabilecek terörist saldırıları önlemek maksadıyla, Deniz Kuvvetlerinin çeşitli yüzer unsurları vasıtasıyla önemli görevler icra edilmektedir. $\mathrm{Bu}$ görevler kapsamında, "Denizel EYPD” saldırılarının geçmiş dönemde yoğun olarak yaşandığı; Kızıldeniz, Bab el-Mandeb, Aden Körfezi ile Hürmüz Boğazı ve Basra Körfezi bölgelerinin risk seviyesi yüksek bölgeler olarak değerlendirilmesi gerekmektedir. Bu bölgelerde görev icra eden unsurların, karşılaşabilecekleri "Denizel EYPD" saldırılarına karşı hareket tarzlarını icra edecekleri gerçeğe yakın eğitimler ile pekiştirmeleri faydalı olacaktır. $\mathrm{Bu}$ unsurların denizde durumsal farkındalıklarının her zaman yüksek seviyede olması ve izleyecekleri rotalar ile ziyaret edecekleri liman bölgelerinin güvenlik zafiyetlerini ve tehdit değerlendirmelerini çok hassas olarak bilmeleri gerekmektedir.

"Deniz Güvenliği”ne tehdit olarak günümüzde pek çok unsur bulunmasına karşın çalışmada odaklanılan tehdit terör örgütlerince kullanılan "Denizel EYPD" ler olmuştur. Bu tehdidin genel olarak özellikleri incelenmiş ve terör örgütlerince kullanılan yöntemlerin günümüze kadar gelen süreçte hangi aşamalardan geçtiği incelenmiştir. Yapılan incelemeler neticesinde, "Denizel EYPD" saldırıları konusunda uzmanlaşmış olduğu düşünülen iki örgütün El-Kaide ve Tamil Kaplanları olduğu görülmüştür. $\mathrm{Bu}$ örgütlerin yakın döneme kadar yüzer unsurlara çeşitli vasıtalar ile gerçekleştirdikleri saldırılar neticesinde verdirdikleri büyük kayıplar deniz ortamındaki gemilerin savunmasızlığını gözler önüne sermiştir. Bugün, askeri gemilerden sivil yolcu gemilerine, süper tankerlerden açık deniz petrol/doğal gaz platformlarına ve deniz ortamındaki kritik alt yapılara kadar birçok unsur bu tehdidin hedefi olma riski taşımaktadır. Önemli deniz ticaret rotalarında, kritik geçitlerde ve boğazlarda, kıyıdaş ülkelerin ve örgütlerin aldığı güvenlik önlemleri, 
her ne kadar terör örgütlerini bu tarz saldırılardan uzak tutsa da, kritik geçitlerde boğazlarda 350 metre uzunluğundaki bir süper tankere veya binlerce yolcu taşıyan bir cruise gemisine düzenlenecek saldırının yaratacağ 1 etki, terör örgütlerinin bu düşüncelerini değiştirebilecek niteliktedir. 11 Eylül saldırılarında havacılık sektöründe görülen güvenlik zafiyetinin, getirilen s1kı güvenlik tedbirleri ile bertaraf edilmesine karşılık, deniz ortamının alınan güvenlik önlemlerine rağmen tam anlamı ile güvenli bir hale getirildiği söylenemez.

Yakın dönem içerisinde deniz ortamında gerçekleştirilen "Denizel EYPD" saldırılarında, insansız uzaktan komutalı bomba yüklü süratli botların kullanımı dikkat çeken en önemli tehdit olarak görülmektedir. Özellikle Deniz Kuvvetleri unsurlarının Kızıldeniz, Bab El-Mandeb ve Hürmüz Boğazı gibi kritik geçitlerde bahse konu tehditlere yönelik durumsal farkındalık seviyesini arttırması gerekmektedir. Gemilerin yakın savunma silahlarının bu tür tehditleri bertaraf edebilecek özelliklere kavuşturulması, bu tehdide karşı önemli bir savunma sağlayabilecektir.

Deniz Kuvvetleri unsurlarının dron tehdidine karşı, açık denizlerde, kıyı sularında ve liman bölgelerinde "Denizel EYPD" lere karşı savunulmasında, teknolojinin sağladığı avantajlar ve kolaylıklardan tam anlamıla yararlanması gerekmektedir. Tehdidin denizden geldiği durumlar için savaş gemilerinin imkân ve kabiliyetlerinde yapılacak iyileştirmeler veya düzenlemeler ile yeterli güvenliğin sağlanabileceği düşünülebilir ancak tehdidin havadan gelmesi durumunda, kapsamlı çözümler üreten firmalar ile birlikte çalışarak, dron savar yeteneklerinin geliştirilmesinin gerekli olduğu düşünülmektedir.

\section{Summary}

As the volume of global commercial activities carried out on $80 \%$ of the world is made in the seas and oceans. Therefore, the security of maritime transportation routes, which we can call the main route of global trade, is vital for countries that is high dependence on this trade. Countries are pursuing a variety of methods to avoid the security weaknesses that merchant ships may encounter on their routes on maritime transport 
routes. In the marine environment, the risks and dangers faced by both merchant and state-owned ships at sea and the ports that support these

Güvenlik Stratejileri

Cilt: 16

Sayı: 34 elements are quite diverse. In order to the protect from risks and threats which is mentioned above that starting from the construction phase of the ships; the designs of machinery, electrical and equipment, fire safety measures, features of life-saving vehicles, cruise safety, principles of transporting dangerous cargoes, documents to be found on ships etc. necessary procedures and take measures, are being implemented. With the implementation of these measures and procedures, the loss of life and property that may be due to the risks and threats that could encountered is reduced to a minimum level.

However, terrorist acts that can be carried out in the marine environment are another factor that needs to be added to the risks and threats mentioned above. if one of the terrorist acts may do in the choke point where international maritime trade carry out, any countrys' port entrance or in the port, serious loss of life and property could be caused and significant damage would be done to the country's economy. For example, USS Cole destroyer was attacked October 12, 2000. This attack was the first terrorist act on a warship in the world, and 17 seafarers died and 42 were injured in that attack. On October 06, 2002, The oil tanker had French-flaged, Linburg was attacked with a small boat, a fire broke out and 57000 tons of crude oil was spilled in the sea, and a major environmental disaster occurred. Improve Explosive Device was used in these both terrorist attacks and their using is increased recent years. As it is seen, The damage caused by IED attacks on sea vehicles by terrorist organizations is enormous. IED needs a certain amount of technical knowledge and skill, if it will be use in marine environment. Although IED does not pose a threat that can be encountered every day but terrorist organizations are worked to develop their skills and methods of attack.

In IED attacks, the use of unmanned remote-controlled bombloaded speedboats that as the most important threat. Particularly, the Navy elements need to increase the situational awareness of these threats in critical passages or choke points such as the Suez Channel and Red Sea, Bab El-Mandeb and Strait of Hormuz. Providing close defensive weapons of ships with features that could eliminate such threats will provide an 
Deniz Ortamında El Yapımı Patlayıcı Düzenek (EYPD)'ler Genelinde

Terörist Tehditler ve Deniz Güvenliğine Etkileri

important defense against this threat. The terrorist organizations are being tried to improve their abilities and capabilities within the framework of developing technology and they could use all kinds of tools and devices for their purposes with their goal. In the defense of both ships and port facilities against IEDs, they need to take full advantage of the advantages and conveniences that technology provide.

\section{KAYNAKÇA \\ Kitaplar}

CHALK Peter. The Maritime Dimension of International Security Terrorism, Piracy, and Challenges for the United States, RAND Project Air Force, California, 2008.

GREENBERG Michael D, CHALK Peter, WILLİS Henry H., KHILLKO Ivan, David S. ORTIZ, Maritime Terrorism Risk and Liability, RAND Project Air Force, California, 2006. HO Joshua, RAYMOND Catherine Zara, The Best Of Times, The Worst Of Times: Maritime Security in the Asia-Pacific, World Scientific Publishing, Londra, 2005.

MURPHY, Martin N., Contemporary Piracy and Maritime Terrorism: The Threat to International Security, International Institute of Strategic Studies, Routledge/Ingiltere, 2007. REVILL, James, Improvised Explosive Devices The Paradigmatic Weapon of New Wars, Palgrave Macmillan, Brighton,UK, 2016.

TOPUZ, Sinan, Modern Deniz Harbini ve Denizler İçin Mücadeleyi Anlamak, Alibi Yayıncılık, Ankara, 2016.

\section{Tezler}

MOCKER Jonathan L. "Maritime Improvised Explosive Devices: A Threat Based Technology Study", Yüksek Lisans Tezi, U.S. Army Command and General Staff College, 2015, https://apps.dtic.mil/dtic/tr/fulltext/u2/a624055.pdf, [Erişim Tarihi: 10.02.2019].

\section{Makaleler}

BUEGER Christian. "What is Maritime Security?", Marine Policy Dergisi, s. 53 (Mart 2015): s.159.

CANLI, Güray Ali, İsmail KURTOĞLU, M.Ozan CANLI, Özgür Selman TUNA. "Dünyada ve Ülkemizde İnsansız Sualtı Araçları (ISAA-AUV \& ROV) Tasarım ve Uygulamaları", ITÜ Gemi İnşaatı ve Deniz Bilimleri Fakültesi Dergisi, s.4, 2015, 43-75.

CHANDRADASA Malaka, Learning from Our Enemies: Sri Lankan Naval Special Warfare against the Sea Tigers, Combating Terrorisim Exchange, Vol.2 No.2, 2012, 1-8.

ESKI Yarın, 'Diving for dope': Identity in submarine drug policing at the 'maritime gateway to Europe', European Journal of Criminology, First Published, November 18, 2019, ss.1-27 https://doi.org/10.1177/1477370819887513. 
378

Güvenlik Stratejileri

Cilt: 16

Sayı: 34
HALBERSTAM Malvina., "Terrorism on the High Seas: The Achille Lauro, Piracy and the IMO Convention on Maritime Safety", The American Journal of International Law, c.88, s.2, 1988, 269-310.

\section{İnternet Kaynakları}

AB Resmi İnternet Sitesi, "Maritime Security Strategy", https://ec.europa.eu/ maritimeaffairs/policy/ maritime-security_en, [Erişim Tarihi: 17.12.2018].

ABD Deniz Kuvvetleri Tarihi Sitesi, http://usnhistory.navylive.dodlive.mil/ 2018/04/23/uss-firebolt-pc10-remembering-heroic-coastal-patrol-ship-sailors-andlooking-forward-to-our-future/, [Erişim Tarihi: 26.01.2019].

ABD Ulusal Güvenlik Departmanı Resmi İnternet Sitesi, Ruth Doherty, "Detect and Defeat Waterborne Improvised Explosive Devices (WBIEDs)," http://www.dhs.gov/xlibrary/ assets/st_detect_and_defeat_waterborne_ied_cied.pdf, [Erişim Tarihi: 26.01.2019].

Action on Armed Violance 2017 Raporu, "Improvised Explosive Device (IED) Monitor 2017", Norveç, 2017, s.26, https://reliefweb.int/sites/reliefweb.int/ files/resources/IED-Monitor-Report-for-web-final.pdf, [Erișim Tarihi: 20.12.2018].

$B B C$ Internet Sitesi, "Bomb caused Philippine ferry fire", http://news.bbc.co.uk/ 2/hi/asia-pacific /3732356.stm, [Erişim Tarihi: 26.01.2019].

BM Resmi Internet Sitesi, "Oceans and the law of the sea", http://www.un.org/en /development/desa/population/migration/generalassembly/docs/globalcompact/A_RES 63 111.pdf, s. 3, [Erișim Tarihi: 17.12.2018].

BM Silahsızlanma Araștırmaları Enstitüsü (UNIDIR), "Addressing Improvised Explosive Devices" Raporu, s.15, http://www.unidir.org/files/publications/pdfs/-en641.pdf, [Erişim Tarihi:18.12.2018].

BM Ticaret ve Kalkınma Konferansı (UNCTAD) 2017 yılı Deniz Taşımacılığı Raporu, "Review Of Maritime Transport 2017", s. 10, https://unctad.org/en/Publications Library/rmt2017en.pdf, [Erişim Tarihi: 17.12.2018].

BM Uluslararası Mühimmat Teknik Rehberi "United Nations International Ammunition Technical Guidelines (IATG) 01.40:2015(E) 2nd Edition (2015-02-01), https://s3.amazonaws.com/unoda-web/wp-content/uploads /2016 /11 /IATG-01.40Glossary-and-Definitions-V.2.pdf, s.16, [Erişim Tarihi: 18.12.2018].

BM Mülteciler Yüksek Komiserliği Resmi Internet Sitesi, https://www.refworld.org /docid/469f38e0c.html. (Erişim Tarihi: 30.04.2020)

BM Güvenlik Konseyi, Yemen Uzmanlar Panel Raporu, 27 Ocak 2020, https://reliefweb.int/sites/reliefweb.int/files/resources/\%5BEN\%5DLetter\%20dated\%2 $027 \% 20 \mathrm{January} \% 202020 \% 20$ from $\% 20$ the $\% 20$ Panel $\% 20 \mathrm{of} \% 20$ Experts $\% 20 \mathrm{on} \% 20 \mathrm{Ye}$ men $\% 20$ addressed $\% 20$ to $\% 20$ the $\% 20$ President $\% 20$ of $\% 20$ the $\% 20$ Security $\% 20$ Council $\% 20-\% 20$ Final $\% 2$ report $\% 20$ of $\% 20$ the $\% 20$ Panel $\% 20$ of $\% 20$ Experts $\% 20$ on $\% 20$ Yemen $\% 20 \% 28$ S-2020-70\%29.pdf(ErișimTarihi: 28. 03. 2020)

CIA Resmi İnternet Sitesi, The Iranian Mine Warfare Threat, https://www.cia.gov/library /readingroom/docs/CIA-RDP85T00314R000300100002-7.pdf(Erișim Tarihi:31.04.2020) "Comprehensive Maritime Barrier Solutions", https://www.halodefense.com/, [Erişim Tarihi: 23.02.2019]. 
Deniz Ortamında El Yapımı Patlayıcı Düzenek (EYPD)'ler Genelinde

Terörist Tehditler ve Deniz Güvenliğine Etkileri

"Defence Innovation Hub showcases maritime counter-IED tech", https://www.defenceconnect.com.au/maritime-antisub/2998-defence-innovation-hubshowcases-maritime-counter-ied-tech, [Erişim Tarihi: 27.03.2019].

"Drone Boat Was Used in Saudi Frigate Attack", https://www.maritime-executive. com/article/drone-boat-used-to-strike-saudi-frigate, [Erişim Tarihi: 30.01.2019].

"European Union Maritime Security Strategy", ttp://register.consilium.europa.eu/ doc/srv?l=EN\&f= ST\%2011205 \%202014\%20 INIT, s. 7, [Erişim Tarihi: 17.12.2018]. Guantanamo Tutuklu Biyografileri, https://archive.defense.gov/pdf/detainee biographies1.pdf, s.7, [Erişim Tarihi: 13.02.2019].

Hürriyet Gazetesi İnternet Sitesi, http://www.hurriyet.com.tr/gundem/hatayda-teknedepatlama-1-sehit-40107334, [Erişim Tarihi: 30.01.2019].

"IMO Deniz Güvenliği Manueli V2", http://www.security.gr/wp-content/uploads/ 2015/03/imo-Maritime-Security-Manual.pdf, [Erişim Tarihi: 17.12.2018].

"Maritime (ISPS Code) Regulations 2014", http://extwprlegs1.fao.org/docs/ pdf/fij152587.pdf, [Erişim Tarihi: 17.12.2018].

Meteksan Kapan Dron Savar Sistemi Broşürü, http://www.meteksan.com/media/file/ kapan-drone-savar-sistemi-brosur_ 1532350611.pdf, [Erişim Tarihi: 23.02.2019].

NATO Resmi İnternet Sitesi, "Alliance Maritime Strategy", https:/www.nato.int/ cps/ua/natohq/official_texts_75615.htm, [Erişim Tarihi: 17.12.2018].

NATO Resmi İnternet Sitesi, "NATO's maritime activities", https://www.nato.int/ cps/en/natohq/topics_70759.htm [Erişim Tarihi: 17.12.2018].

OECD Maritime Transport Committee, "Security in Maritime Transport: Risk Factors and Economic Impact", Ekonomik Kalkınma ve İş Birliği Örgütü (OECD) Raporu 2003, s. 3, http://www.oecd.org/newsroom/4375896.pdf, [Erişim Tarihi: 13.02.2019].

"PKK'nın gizli drone üssü", https://www.cnnturk.com/turkiye/pkknin-gizli-droneussu, [Erişim Tarihi: 23.02.2019].

"PNS Zulfiqar Attack Five Navy Officers Get Death Penalty" https://tribune.com.pk/story/ 1110057/pns-zulfiqar-attack-five-navy-officers-get-death-penalty/, [Erişim Tarihi: 26.03.2019].

"PRIED (Portable Raman Improvised Explosive Detector)", https://www.epequip.com/ catalogue/all-hazards-management/pried/, [Erişim Tarihi: 27.03.2019].

"RSN Al Madinah (Saudi Arabia)", http://www.wbied.com/case-studies/rsn-almadinah-saudi-arabia/, [Erişim Tarihi: 30.01.2019].

"Saudi Forces Find More Naval Mines Off Yemen", https://www.maritime-executive. com/article/saudi-forces-find-more-naval-mines-off-yemen, [Erişim Tarihi: 23.02.2019].

"Small boats, big problems: Navy blocks attacks from the sea with floating barriers", https://techlinkcenter.org/truston -port-security/, [Erişim Tarihi: 23.02.2019].

“Teröristler Şırnak'ta 8 model uçakla saldırı düzenledi”, https://www.haberturk.com/ teroristler-sirnak-ta-8-model-ucakla-saldiri-duzenledi-2216071, [Erişim Tarihi: 23.02.2019].

"The Creation of the Highly Effective Limpet Mine", https:/www.warhistory online.com/instant-articles/creation-of-the-limpet-mine.html, [Erişim Tarihi: 18.02.2019].

The Economist Dergisi Internet Sitesi, "In Guantánamo, an alleged al-Qaeda killer 
380

Güvenlik Stratejileri

Cilt: 16

Sayı: 34

awaits trial", https://www.economist.com/international/2017/01/14/in-guantanamo-analleged-al-qaeda-killer-awaits-trial, [Erişim Tarihi: 13.02.2019].

Türkiye Cumhuriyeti Dişişleri Bakanlığı Resmi İnternet Sitesi, http://www.mfa.gov.tr/yemen-siyasi-gorunumu.tr.mfa, [Erişim Tarihi: 30.01.2019].

"U.S. Navy Awards DetectaChem Hand Held Explosive Detector (HHED) Contract", https://detectachem.com/?gclid=CjwKCAjwvuzkBRAhEiwA9E3FUIUV8fSCJGMQL wi8R5suJVhrILujwJenYyBsG0X_ aAM9b6QmKSawRoC7ykQAvD_BwE, [ErişimTarihi:27.03. 2019].

"USS Cole INVESTRPT.Pdf", https://www.history.navy.mil/content/dam/nhhc/ browse-by-topic/ships/uss-cole/pdf/INVESTRPT.pdf, s.8. [Erişim Tarihi: 17.12.2018]. Uluslararast Denizcilik Örgütü Resmi Internet Sitesi, http://www.imo.org/ en/About/Pages/Structure.aspx, [Erişim Tarihi: 17.12.2018]

Wall Street Journal, https://www.wsj.com/articles/al-qaeda-militants-tried-to-seizepakistan-navy-frigate-1410884514 (Erişim Tarihi: 31.03.2020)

BONOMO James, BERGAMO Giacomo, FRELINGER David R., GORDON John and Brian A. JACKSON, Stealing the Sword, What Types of Advanced Military Weapons Could Become Available to Terrorists?, RAND Corporation, 2007, s.2. https://www.jstor.org/stable/10.7249/mg510dhs.10?seq

=1\#metadata_info_tab_contents (Erişim Tarihi: 31.03 .2020 )

CAVAS Christopher P. "New Houthi weapon emerges: a drone boat", https://www.defensenews.com/digital-show-dailies/idex/2017/02/19/new-houthiweapon-emerges-a-drone-boat/, (19.02.2017), [Erişim Tarihi: 30.01.2019].

LORENZ Akiva J. "Al Qaeda's Maritime Threat", Intelligence and Terrorism Information Center at the Israel Intelligence Heritage \& Commemoration Center (IICC), 3 May1s 2007, s. 13, http://citeseerx.ist.psu.edu/viewdoc/download?doi= 10.1.1.473.6168\&rep=rep1\&type=pdf, [Erişim Tarihi: 13.02.2019].

MARTIN Christopher. "The Historical Use of Maritime Improvised Explosive Devices", Hull Universit Centre for Security Studies IED Project Occasional Paper No. 1, 2010, s. 8, http://www.wbied.com/-content/uploads/2015/08/wbied.com_CSSOccasional-Paper-1.pdf, [Erişim Tarihi: 10.02.2019].

MOORE Ashley, "Needed: Revisions to Maritime Response Standard", https://www.domprep.com/resilience/needed-revisions-to-maritime-responsestandard/[Erişim Tarihi: 13.02.2019].

RAMACHANDRAN, Sudha. "The Sea Tigers of Tamil Eelam," Asia Times İnternet Sitesi, 31 Ağustos 2006, http://www.atimes.com/atimes/South_Asia/HH31Df01.html, [Erişim Tarihi: 26.01.2019].

SIMON Jeffrey D. "The Implications Of The Achille Lauro Hijacking For The Maritime Community", https://apps.dtic.mil/ dtic/tr /fulltext/u2/a178441.pdf [Erişim Tarihi: 21.12.2018].

SNOW, Shawn. "Here's why the Corps strapped a counter-drone system to the deck of a warship in the Suez Canal", https://www.marinecorpstimes.com/news/your-marinecorps/2019/01/31/the-corps-strapped-a-new-counter-drone-system-to-the-deck-of-awarship-transiting-the-suez-canal-heres-why/, [Erişim Tarihi: 23.03.2019]. 
Deniz Ortamında El Yapımı Patlayıcı Düzenek (EYPD)'ler Genelinde

Terörist Tehditler ve Deniz Güvenliğine Etkileri

SOLACE Global Maritime Advisory Raporu 8 Mart 2018, "Water Borne Improvised Explosive Devices (WBIED)", s. 4, https://www.solaceglobal.com/wpcontent/uploads/2018/03/20180308- Maritime-Advisory-History-and-Usage-of-WaterBorne-Improvised-Explosive-Devices-1.pdf, [Erişim Tarihi: 30.01.2019].

TOMASI Marco D. "Water-borne IED Threats and the Strait of Hormuz", Joint IED Defeat Organization (JIEDDO) 2009 Raporu, s. 2, https://info.publicintelligence .net/JIEDDO-Hormuz.pdf, [Erişim Tarihi: 26.01.2019].

\section{1}

Güvenlik Stratejileri Cilt: 16

Say1: 34 